\title{
Contribution of Excited Ozone and Oxygen Molecules to the Formation of the Stratospheric Ozone Layer
}

\author{
Kari Hänninen \\ Department of Biological and Environmental Sciences, Jyväskylä University, Finland
}

Copyright $\odot 2019$ by authors, all rights reserved. Authors agree that this article remains permanently open access under the terms of the Creative Commons Attribution License 4.0 International License

\begin{abstract}
The absorption of UV, visible and near IR radiation by $\mathrm{O}_{3}$ produces transient, electronically excited $\mathrm{O}_{3}$. The absorption of thermal IR radiation $(\lambda=9.065$, 9.596 and $14.267 \mu \mathrm{m})$ produces vibrationally excited $\mathrm{O}_{3}$ molecules. Thermal absorption is likely the main factor in the self-decay of $\mathrm{O}_{3}$. Photoexcitation of ground state $\mathrm{O}_{2}$ $\left(\mathrm{X}^{3} \Sigma_{\mathrm{g}}^{-}\right)$by IR and red light radiation produces singlet oxygens $\left(\mathrm{O}_{2}\left(\mathrm{a}^{1} \Delta_{\mathrm{g}}\right)\right.$ and $\left.\mathrm{O}_{2}\left(\mathrm{~b}^{1} \Sigma_{g}^{+}\right)\right)$. Chemical reactions in the stratosphere produce them as well. When reacting with ozone, singlet oxygen produces $\mathrm{O}\left({ }^{3} \mathrm{P}\right)$ and $\mathrm{O}_{2}\left(\mathrm{X}^{3} \Sigma_{\mathrm{g}}^{-}\right)$. By doing so, they tend to maintain the prevailing ozone concentration and are thereby important for the stability of the ozone layer. During the daytime, $\mathrm{O}\left({ }^{1} \mathrm{D}\right), \mathrm{O}_{2}\left(\mathrm{a}^{1} \Delta_{\mathrm{g}}\right)$ and $\mathrm{O}_{2}\left(\mathrm{~b}^{1} \Sigma_{\mathrm{g}}{ }^{+}\right)$reach their maximum concentrations at altitudes of 45 to $48 \mathrm{~km}$. This manifests fast ozone turnover which generates the maximum stratospheric temperature at those particular altitudes. During the night-time, the self-decay of ozone and absorption of light from the nightglows, moon and stars by $\mathrm{O}_{3}$ and $\mathrm{O}_{2}$ generates so much heat that the stratospheric temperature decreases by only a couple of degrees. Being a heavier gas than $\mathrm{O}_{2}$ and $\mathrm{N}_{2}$, ozone lacks buoyancy in the atmosphere, and it starts to descend immediately when formed. Chapman calculated that ozone in the stratosphere would descend $20 \mathrm{~m}$ per day. At the North and South Poles, during the four to six months of darkness in the winter, ozone descends by 2.4 to $3.6 \mathrm{~km}$. This descent is likely the main reason for the stratospheric ozone depletion above the poles during winter.
\end{abstract}

Keywords Ozone Self-decay, Photoexcitation of Ground State $\mathrm{O}_{2}$ Molecule to Singlet Oxygens by IR and Red Light, Importance of Singlet Oxygens for the Stability of the Ozone Layer, Reason for Ozone Depletion above the Poles during Winter

\section{Introduction}

At the beginning of the 20th century, it was found that the emissions of stars contribute to only a part of the total night-sky emission intensity in the visible range [1]. By the late 1920s, it became obvious that Earth's atmosphere exists at high altitudes as well, and important chemical processes occur there, such as the green line nightglow of oxygen atoms (OI 5577 $\AA$ ) [2]. It became evident that excited $\mathrm{O}$ and $\mathrm{O}_{2}$ are present in the atmosphere, because features of the day and night airglows derive optical transitions from these species. The development of quantum and molecular orbital theories provided explanations for the observed phenomena, and led to the development of modern aeronomy.

Singlet oxygen, ${ }^{1} \mathrm{O}_{2}$ (present notation $\mathrm{O}_{2}\left(\mathrm{a}^{1} \Delta_{\mathrm{g}}\right)$ ), was first observed in 1924 [3] and it was then defined as a more reactive form of oxygen molecule. UV nightglow was explained to be due to the relaxation of even more highly excited oxygen molecules [4]. In 1939, Kautsky [5] first proposed that ${ }^{1} \mathrm{O}_{2}$ might be a reaction intermediate in dye-sensitized photooxygenation. The study of excited oxygen molecules has since become an important goal in physical chemistry [6, 7].

In the 1930s, Sydney Chapman proposed a kinetic model for the production and destruction of stratospheric ozone (the oxygen-only theory) [8]. Chapman's mechanism involves two photochemical, (1) and (2) and three chemical reactions, (3) to (5) [9].

$$
\begin{gathered}
\mathrm{O}_{2}+\mathrm{h} v \rightarrow \mathrm{O}+\mathrm{O} \\
\mathrm{O}_{3}+\mathrm{h} v \rightarrow \mathrm{O}+\mathrm{O}_{2} \\
\mathrm{O}+\mathrm{O}_{2}+\mathrm{M} \rightarrow \mathrm{O}_{3}+\mathrm{M} \\
\mathrm{O}+\mathrm{O}_{3} \rightarrow \mathrm{O}_{2}+\mathrm{O}_{2} \\
\mathrm{O}+\mathrm{O}+\mathrm{M} \rightarrow \mathrm{O}_{2}+\mathrm{M}
\end{gathered}
$$

According to the theory, the net production of oxygen atoms results almost exclusively from the photodissociation of molecular oxygen (1). Ozone is formed via a single recombination reaction of atomic and molecular oxygen (3). Photolysis (2) and the reformation of ozone (3) would have no ultimate net effect on the amount of ozone. Under usual stratospheric conditions, $\mathrm{O}_{3}$ photolysis (2) is $10^{3}$ times faster than the dissociation of $\mathrm{O}_{2}$ (1). Reaction (3) is to a similar degree faster than (4) and (5) 
for O removal [9].

Originally, Chapman included (6) in his mechanism as well. He considered that it would describe the thermal decomposition of ozone. In technological applications the temperature-dependent self-decay of ozone is presently well realized [10].

$$
\mathrm{O}_{3}+\mathrm{O}_{3} \rightarrow 3 \mathrm{O}_{2}
$$

Chapman also makes a note that ozone is a heavier gas than $\mathrm{O}_{2}$ and $\mathrm{N}_{2}$, implying that it descends in the atmosphere due to gravity. He calculated that at an altitude of $50 \mathrm{~km}$ ozone would descend even $20 \mathrm{~m}$ per day. Excited oxygen and/or ozone molecules had no role in Chapman's theory.

In the 1970s, the existence of vibrationally and electronically excited states of ozone was proven theoretically [11]. At the same time, the global upper mesosphere and lower thermosphere (MLT) ozone maximum were also discovered [12-14]. A third ozone maximum was found in the 1990s. It was named, according to its vertical location, as the middle mesospheric (tertiary) maximum of ozone (MMM). In the Northern Hemisphere its location is restricted to between the mid-latitudes and somewhat north from the Arctic Circle during the winter months [15].

It turned out that the models, based on (1) to (5) of the Chapman cycle, predicted ozone concentrations that are smaller compared to the observed concentrations. In the 40 to $45 \mathrm{~km}$ region, the error was about $10 \%$ to $20 \%$, its magnitude increasing with altitude [16-18].

In computer models it is assumed that the ozone layer is so homogeneous and static that it would enable the use of linear equations to model the stratospheric ozone behavior. This concept has been criticized by the Crista researchers [19]. According to them, 3-D images demonstrate that ozone is organized in complex dynamic vertical and filamentary structures that are constantly changing. Considering the inhomogeneous distribution of ozone in the atmosphere, the approach to restrict it to a certain ideal fixed frame of average thickness does not seem relevant. Attempts to model complex nonlinear processes with zonal averaging and linear equations will invariably give inaccurate results. The Chapman cycle, however, has remained at the core of the models of ozone kinetics used by current atmospheric scientists [20].

Chapman's model needs to be expanded by considering the excited states of $\mathrm{O}_{2}$ and $\mathrm{O}_{3}$ molecules, the reactions of which with ground state $\mathrm{O}_{2}$ molecule $\left(\mathrm{O}_{2}\left(\mathrm{X}^{3} \Sigma_{\mathrm{g}}^{-}\right)\right)$also produce unpaired oxygen species. Their contribution would be important when comprehensively explaining the dynamic behavior of ozone in the atmosphere.

\section{Materials and Methods}

\subsection{Aims of the Study}

The aim of this meta-study is to provide a basic understanding of the dynamics related to the formation of the stratospheric ozone layer. For this purpose, important new variables are discussed, including the downward movement of ozone due to its lack of buoyancy, the temperature-dependent self-decay of ozone, and the importance of the excited states of $\mathrm{O}_{3}$ and $\mathrm{O}_{2}$ molecules in the dynamics of the stratospheric ozone layer.

This study is based on available satellite data regarding the existence of $\mathrm{O}_{3}$ and excited $\mathrm{O}_{2}$ molecules in the atmosphere as well as on the published physical and chemical (practical and theoretical) research on their formation and reactions.

\subsection{Formulas Used in Calculations}

The formation enthalpies of reactions are calculated according to Hess's Law by (7):

$$
\Delta \mathrm{H}_{\mathrm{f} \text { (reaction) }}^{\circ}=\Delta \mathrm{H}_{\mathrm{f} \text { (products) }}^{\circ}-\Delta \mathrm{H}_{\mathrm{f} \text { (reactants) }}^{\circ}
$$

If the difference of $\Delta \mathrm{H}_{\mathrm{f} \text { (products) }}^{\circ}-\Delta \mathrm{H}_{\mathrm{f} \text { (reactants) }}^{\circ}<$, the reaction is exothermic and it will proceed spontaneously. In the text, the notation $\Delta \mathrm{H}^{\circ}$ is used instead of $\Delta \mathrm{H}^{\circ}$.

$$
\lambda=\mathrm{hcN}_{\mathrm{A}} \mathrm{E}
$$

The relationship between energy and the wavelength of electromagnetic radiation is calculated by (8) [21].

The formation enthalpies $(\mathrm{kJ} / \mathrm{mol})$ used are as follows: for ozone 142.7 , for $\mathrm{O}\left({ }^{3} \mathrm{P}\right) 249.2$, for $\mathrm{O}\left({ }^{1} \mathrm{D}\right) 438.9$ and for $\mathrm{O}\left({ }^{1} \mathrm{~S}\right)$ 653. The relationships between energy units $\mathrm{eV}$, $\mathrm{kJ} / \mathrm{mol}$ and $\mathrm{cm}^{-1}$ are $1 \mathrm{eV}=96.49 \mathrm{~kJ} / \mathrm{mol}=8064 \mathrm{~cm}^{-1}, 1$ $\mathrm{kcal}=4.184 \mathrm{~kJ}[22]$.

\section{Discussion}

\subsection{Attenuation of the Solar Radiation in the Atmosphere}

Ultraviolet radiation (UV) includes wavelengths between 10 and $400 \mathrm{~nm}$. By convention, it is subdivided into extreme UV (EUV, or XUV: 10-110 nm), far UV (FUV: $110-200 \mathrm{~nm})$, UVC (200-280 nm), UVB (280-320 $\mathrm{nm})$, and UVA (320-400 $\mathrm{nm}$ ) regions. Wavelengths of 10 to $200 \mathrm{~nm}$ are also called vacuum ultraviolet (VUV), because ground-level instruments are usually placed under a vacuum to obtain sufficient light transmission in this region [23]. The exact division between the EUV and the FUV is frequently considered to be the ionization threshold of molecular oxygen at $102.8 \mathrm{~nm}$ [23]. UV radiation is attenuated in the atmosphere by absorption and scattering [24]. Absorptions define the absorptive optical thickness of the atmosphere, and scatterings the non-absorptive optical thickness of the atmosphere.

\subsubsection{Absorptive Attenuation of UV Light: Effect of Nitrogen and Oxygen Species}

In the thermosphere, absorptive shielding of the atmosphere towards EUV radiation is provided by $\mathrm{N}, \mathrm{N}_{2}, \mathrm{O}$ 
and $\mathrm{O}_{2}$ species. Nitrogen atoms absorb EUV especially in the 61.2 to $69.4 \mathrm{~nm}$ region [25]. Molecular nitrogen has strong absorption bands in the range of 80 to $100 \mathrm{~nm}$ [26]. Oxygen atoms absorb EUV photons in the range of 60 to $100 \mathrm{~nm}$, singlet oxygens $\mathrm{O}_{2}\left(\mathrm{a}^{1} \Delta_{g}\right)$ and $\mathrm{O}_{2}\left(\mathrm{~b}^{1} \Sigma_{g}^{+}\right)$absorb EUV in the region of 83.5 to $90.0 \mathrm{~nm}$ [27].

Absorption of $\mathrm{O}_{2}$ and $\mathrm{O}_{3}$ attenuates the FUV and UVC in the mesosphere and stratosphere. $\mathrm{O}_{2}$ has a continuous UV absorption band (with decreasing intensity) at the wavelengths of 105 to $252 \mathrm{~nm} . \mathrm{O}_{3}$ absorbs continuously (with variable intensity) at the wavelengths of 105 to 1100 $\mathrm{nm}$ (See Figure 1) [28, 29]. The release of energy when UV photons are absorbed by $\mathrm{O}_{3}$ is the main source for heating the stratosphere during daytime.

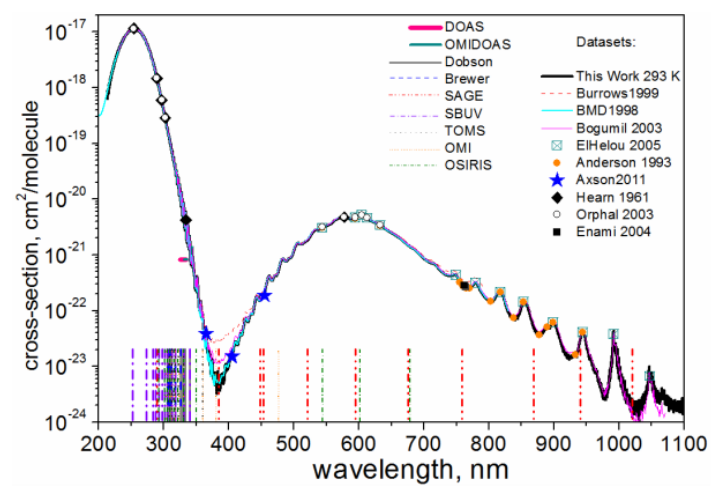

Figure 1. Transmittance Spectrum of $\mathrm{O}_{2}$ in the Visible and Near IR bands [29]

3.1.2. Absorption of Red and IR Light by $\mathrm{O}_{3}$ and $\mathrm{O}_{2}$

$\mathrm{O}_{3}$ absorbs red light at wavelengths of 540 to $640 \mathrm{~nm}$ (see Figure 1) [29]. Absorption of those wavelengths starts in the lower thermosphere. At an altitude of $4.6 \mathrm{~km}$, the cumulative effect of the $\mathrm{O}_{3}$ absorption of red light is considerable (see Figure 2). These absorptions probably intensify the overall feeling of blueness in the sky. Rayleigh scattering is the main reason for blue sky.

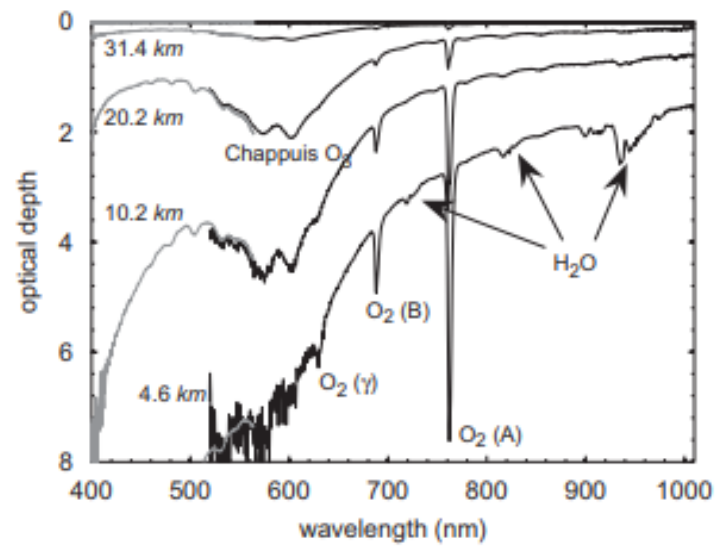

Figure 2. The UV-Vis (grey) and Vis-NIR (black) optical depth spectra from sunset observation (3 March 2004, 79:8 ${ }^{\circ} \mathrm{N}, 80: 5^{\circ} \mathrm{W}$ ), shown for four sample tangent heights. An optical depth of 8 corresponds to a transmission of $0.03 \%$ [30]
$\mathrm{O}_{3}$ absorbs IR at wavelengths of 750 to $900 \mathrm{~nm}$ and 920 to $1060 \mathrm{~nm}$ (the Wulf bands) [29].

$\mathrm{O}_{2}$ absorbs IR at the wavelength $\mathrm{s}$ of $1065 \mathrm{~nm}$ and 1269 $\mathrm{nm}$ [31]. Red light it absorbs at the wavelengths of $\lambda=627$ to $637 \mathrm{~nm}, \lambda=685$ to $697 \mathrm{~nm}$ and $\lambda=758$ to $772 \mathrm{~nm}$, the $\mathrm{A}$, $\mathrm{B}$ and $\Upsilon$-bands of $\mathrm{O}_{2}$ respectively [30, 32].

IR absorption by $\mathrm{O}_{2}$ and $\mathrm{O}_{3}$ prevents some of the solar IR and most of the nightglows' IR from reaching the ground. The release of energy when visible and IR photons and UV photons (from UV nightglows) are absorbed by $\mathrm{O}_{3}$ is an important source of energy for heating the stratosphere during the night.

\subsubsection{Attenuation of Solar Light by Inelastic and Elastic Scattering}

EUV photons with wavelengths of 10 to $50 \mathrm{~nm}$ are screened off by inelastic scattering (in which photons lose energy) already in the thermosphere. Collisions produce photoelectrons [2]. They have enough energy to carry out further ionization reactions [33]. Ionizations caused by EUV creates the ionosphere of Earth.

When photons of UVC, UVB, UVA and blue light collide with $\mathrm{N}_{2}$ and $\mathrm{O}_{2}$ molecules, they are subjected to elastic Rayleigh scattering in the mesosphere, stratosphere and troposphere. At this point photons do not lose energy, only their direction of movement is changed. From the lower stratosphere down the Rayleigh scattering becomes increasingly important.

The deviate portion of solar radiation is called skylight. It comes from all regions of the sky. This means that one can, for example, get a tan even when under a small umbrella at the beach or when skiing on powder snow on a sunny day.

It is estimated that the "sky" portion contributes $15 \%$ to $25 \%$ of total downwelling irradiance in the blue light region (400 to $500 \mathrm{~nm}$ ). In the UVA region it contributes $25 \%$ to $50 \%$. In the UVB region it contributes $50 \%$ to nearly $100 \%$ [34].

Only the longer part of UVB $(290 \leq \lambda \leq 320 \mathrm{~nm})$, depending on the latitude, reaches the ground [35]. Rayleigh scattering eliminates the most energetic part of the UVB (280 nm $\leq \lambda \leq 290 \mathrm{~nm}$ ), so that only traces of it reach the lower troposphere [36].

\subsection{Stratospheric Ozone Layer}

\subsubsection{Boundaries of the Stratosphere}

The height of the tropopause depends on the latitude and the season. During the summer monsoon, the height of the tropopause may be as much as $18 \mathrm{~km}$ over southwest Asia. At the midlatitudes, the tropopause is less than 9 to $10 \mathrm{~km}$ above sea level. In winter above Antarctica, Siberia and northern Canada its height is $8 \mathrm{~km}$ [37]. The lower boundary of the stratosphere varies accordingly.

Above India the stratopause is, on average, at an altitude 
of 47 to $48 \mathrm{~km}$ with a standard deviation of $3.2 \mathrm{~km}$ [38]. Above Germany its altitude is between 47 and $49 \mathrm{~km}$ [39].

\subsection{Temperature Profile of the Stratosphere}

Above Germany the stratospheric temperature increases with altitude at an average of $5{ }^{\circ} \mathrm{C}$ per $\mathrm{km}$. The maximum temperature is reached at the altitude range of 45 to $48 \mathrm{~km}$. From the stratopause upwards, the temperature of the mesosphere decreases (see Figure 3).

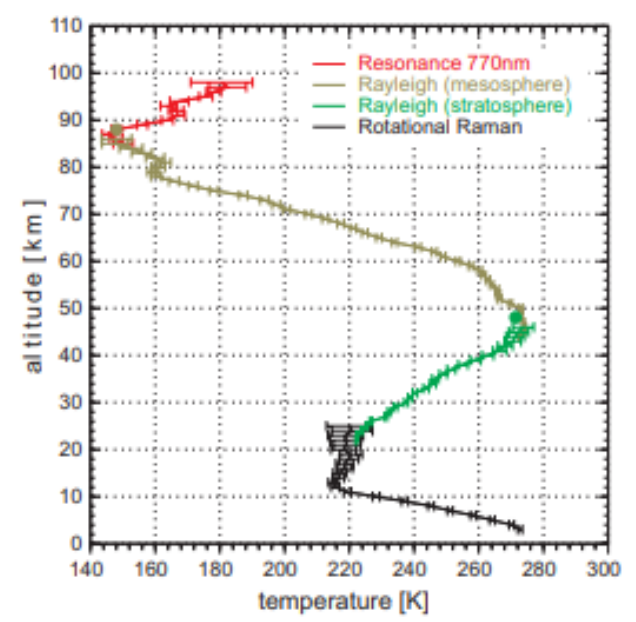

Figure 3. Nighttime Temperature Profile of the Atmosphere above Germany in June 2005 [39]

The stratopause temperatures above India range from 248 to $279 \mathrm{~K}$ with maximum frequency of occurrence in the temperature range of 261 to $262 \mathrm{~K}$ [38]. Above Germany the summer stratopause $(\sim 275 \mathrm{~K})$ is slightly warmer than the winter stratopause ( 266 K) [39].

During the night the stratosphere cools a bit. Diurnal temperature difference between 20 and $48 \mathrm{~km}$ is 1 to 2 degrees. From the stratopause upwards in the mesosphere, the diurnal temperature difference increases (see Figure 4).

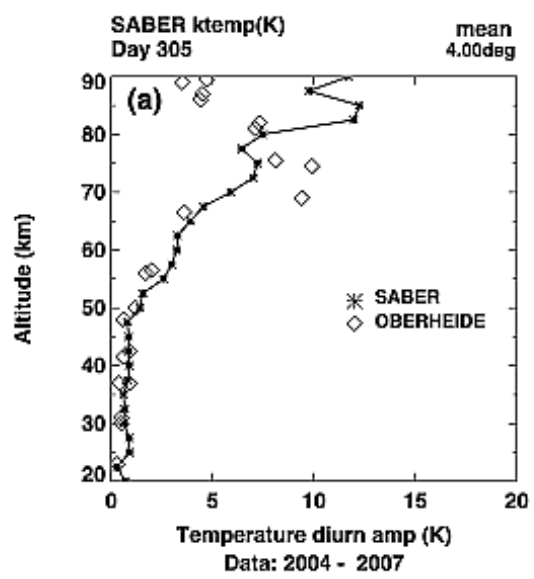

Figure 4. Diurnal Temperature Amplitude in the Stratosphere and Mesosphere [40]

\subsubsection{Elevations of VMR and Number Density Maxima of Ozone}

The maximum volume mixing ratio (VMR) of ozone ( 9 to $10 \mathrm{ppm}$ ) is centered at the altitude of $32 \mathrm{~km}$ between 20 ${ }^{\circ} \mathrm{S}$ to $20^{\circ} \mathrm{N}$ (see Figure 5). On the other hand, the maximum number density of ozone is centered at altitudes of 15 to 25 $\mathrm{km}$ [41]. VMR and number density maxima do not coincide at the same altitude because the density of the air decreases ten times when going from 20 to $35 \mathrm{~km}$ [42]. At $20 \mathrm{~km}$, the VMR of 3 ppm contains three times more ozone molecules than the VMR of $10 \mathrm{ppm}$ at $35 \mathrm{~km}$.

During the winter, between the midlatitudes and boreal areas, the number density maximum of ozone $\left(5-6 \times 10^{12}\right.$ $\mathrm{cm}^{-3}$ ) is located at altitudes of 15 to $20 \mathrm{~km}$ [43].

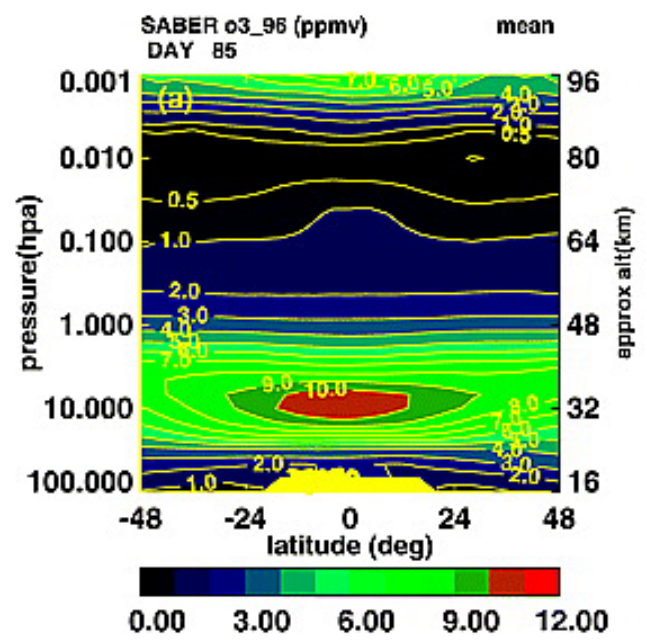

Figure 5. Ozone VMR in the Stratosphere and Mesosphere [40]

\subsection{Diurnal Variation of the VMR of Ozone in the Stratosphere}

Parrish et al. [44] measured the day-night variation of $\mathrm{O}_{3}$ VMR for each hour of the day over the summer months (June, July, and August) from 1995 to 2013 above Hawaii (see Figure 6).

Between altitudes of 20 to $27 \mathrm{~km}$, the $\mathrm{O}_{3}$ concentrations are more or less the same during the day and night. Within this range UV photons with $\lambda<252 \mathrm{~nm}$ are screened off due to the great absorptive optical density of the atmosphere. So, the dissociation of $\mathrm{O}_{2}(1)$ does not produce $\mathrm{O}$ atoms. The photolysis of $\mathrm{O}_{3}(2)$ and the self-decay of ozone are more or less the sole contributors of $\mathrm{O}$ atoms. Reaction (3) is able to produce enough new $\mathrm{O}_{3}$, concentration of which remains stable.

A notable exception is the afternoon minimum of $\mathrm{O}_{3}$ at altitudes of 20 to $24 \mathrm{~km}$. The non-absorptive optical density of the atmosphere at this altitude is already so great that the Rayleigh scattering has importance. For this reason, there is more energetic UV radiation available in the afternoon. The photolysis of $\mathrm{O}_{3}$ increases. Reaction (3) is not able to produce enough new $\mathrm{O}_{3}$, concentration of which subsequently decreases.

At altitudes of 31 to $39 \mathrm{~km}$, the UV radiation in the morning is capable of photolyzing $\mathrm{O}_{3}$, but not of dissociating enough $\mathrm{O}_{2}$. Due to the lack of $\mathrm{O}$ atoms, the $\mathrm{O}_{3}$ concentration is kept low. The morning minimum of $\mathrm{O}_{3}$ is created. By midday the proportion of more energetic UV 
photons increases and dissociating of $\mathrm{O}_{2}$ is higher. The produced $\mathrm{O}$ atoms fuel the formation of $\mathrm{O}_{3}$ via (3). The $\mathrm{O}_{3}$ concentration reaches its afternoon maximum.

At altitudes of 42 to $46 \mathrm{~km}$, the UV is already in the morning as strong as it is at altitudes of 31 to $39 \mathrm{~km}$ at midday. The $\mathrm{O}_{3}$ maximum is now created in the morning. Around midday the production of $\mathrm{O}$ atoms increases due to higher $\mathrm{O}_{2}$ dissociation. However, for two reasons this is not enough to boost $\mathrm{O}_{3}$ formation. First, the rate of $\mathrm{O}_{3}$ photolysis increases even more than that of $\mathrm{O}_{2}$ dissociation. Second, the rate of (3) depends on the abundance of a third body $\mathrm{M}$, and therefore on pressure. The air pressure is already so low that the availability of $\mathrm{M}$ molecules limits the rate of (3). As a consequence, concentration of $\mathrm{O}_{3}$ is depleted in the afternoon. However, in spite of this the overall ozone turnover is so great that the stratospheric temperature reaches its maximum within the range 45 to 48 $\mathrm{km}$.

From $48 \mathrm{~km}$ upwards, UV radiation is intensive enough already from the morning. However, the abundance of $\mathrm{M}$ decreases increasingly and so does the rate of (3) as well. Concentration of $\mathrm{O}_{3}$ remains low all day. Overall ozone turnover starts to decrease, and temperature starts to decrease.

\subsection{Excited States of Ozone Molecules}

\subsubsection{Structure of Ozone Molecule}

Ozone is an allotropic form of oxygen constituted of 3 oxygen atoms. It has 24 electrons, of which 6 are in the 3 closed shell inner orbitals, and 18 valence electrons are in 12 outer orbitals [45].

In the $a b$ initio calculations, ozone is considered to have three structural symmetries (a type of conformational isomer): the $\mathrm{C}_{2 \mathrm{v}}$ (open) minimum, the $\mathrm{D}_{3 \mathrm{~h}}$ (ring) minimum, and the $\mathrm{O}\left({ }^{3} \mathrm{P}\right)+\mathrm{O}_{2}\left(\mathrm{X}^{3} \Sigma_{g}\right)$ dissociation threshold. In the calculations the barrier to isomerization (open $\rightarrow$ ring $\rightarrow$ open) is taken to be about $1.3 \mathrm{eV}(125.4 \mathrm{~kJ} / \mathrm{mol})$ with respect to the dissociation asymptote. The ground electronic state of ozone (in the open minimum conformation) has ${ }^{1} \mathrm{~A}_{1}$ vibrational symmetry [46]. Like $\mathrm{O}_{2}$, $\mathrm{O}_{3}$ molecule has a multitude of electronically excited as well as vibrationally excited states. The excited states have a much weaker $\mathrm{O}_{2}-\mathrm{O}$ bond and hence may lead to much faster reaction rates with various atoms and molecules.

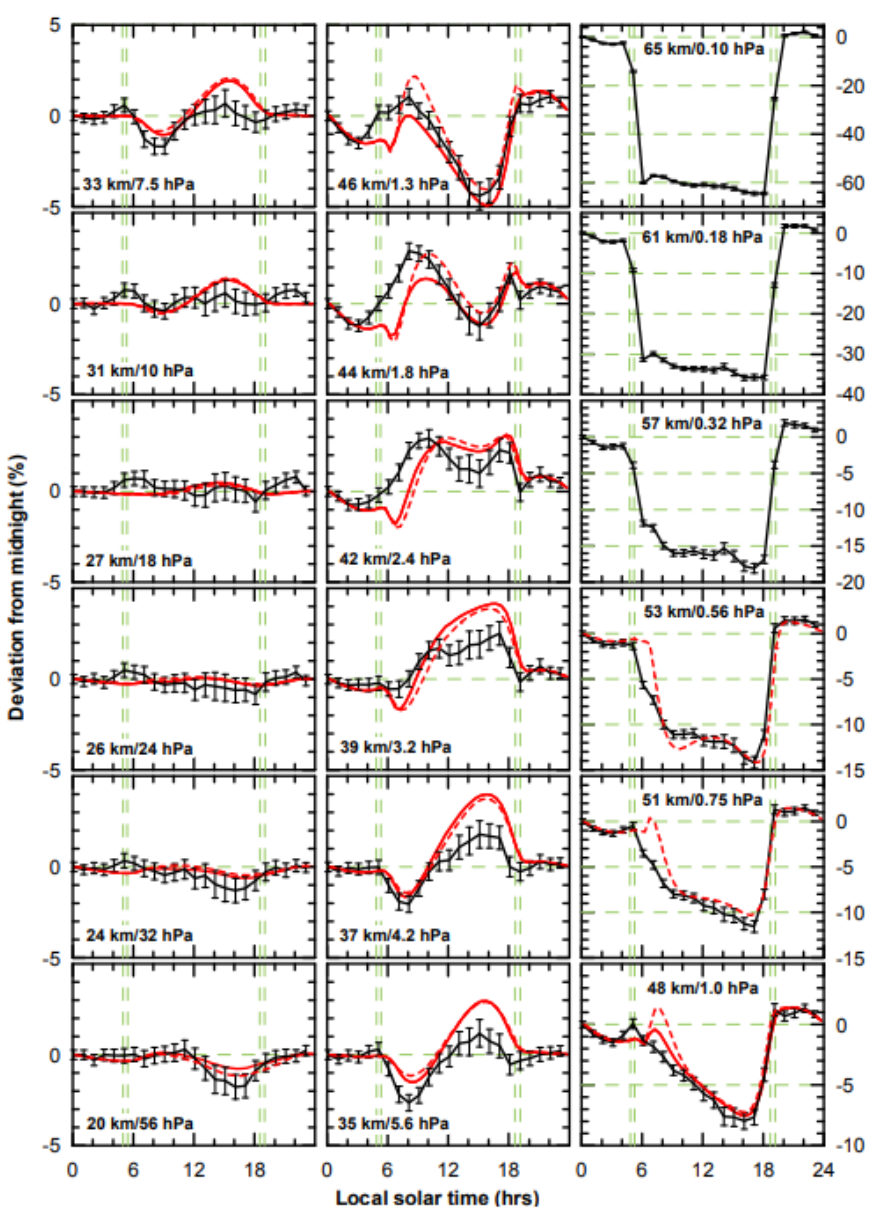

Figure 6. Day-night difference of measured (black) and modeled (solid and dashed red lines) ozone values for each hour of the day in summer (June, July, and August), normalized to the corresponding midnight values. Measured values are derived from selected MWR data, averaged over the summer months from 1995 to 2013, at pressure levels between $56 \mathrm{hPa}$ to $0.1 \mathrm{hPa}$ [44] 


\subsubsection{Electronically Excited Ozone Molecules}

The chemistry of the electronically excited ozone molecules is not as straightforward as that of electronically excited oxygen molecules. Already the energy of the lowest excited electronic state of $\mathrm{O}_{3}$ is above its dissociation threshold $\mathrm{O}\left({ }^{3} \mathrm{P}\right)+\mathrm{O}_{2}\left(\mathrm{X}^{3} \Sigma_{g}{ }^{-}\right)$. Only the lowest triplet states have so long lifetimes that they likely participate bimolecular reactions in the atmosphere. More highly excited (singlet) states are dissociated immediately. That is why the electronically excited states of $\mathrm{O}_{3}$ are categorized according to the energies of their photolysis products. Relevant reactions in the stratosphere are [45]:

$$
\begin{aligned}
& \mathrm{O}_{3}+\mathrm{h} v(\lambda<1180 \mathrm{~nm}) \rightarrow \mathrm{O}\left({ }^{3} \mathrm{P}+\mathrm{O}_{2}\left(\mathrm{X}^{3} \Sigma_{g}{ }^{-}\right)\right. \\
& \mathrm{O}_{3}+\mathrm{h} v(\lambda<612 \mathrm{~nm}) \rightarrow \mathrm{O}\left({ }^{3} \mathrm{P}\right)+\mathrm{O}_{2}\left({ }^{1} \Delta_{g}\right) \\
& \mathrm{O}_{3}+\mathrm{h} v(\lambda<463 \mathrm{~nm}) \rightarrow \mathrm{O}\left({ }^{3} \mathrm{P}\right)+\mathrm{O}_{2}\left(\mathrm{~b}^{1} \Sigma_{g}^{+}\right) \\
& \mathrm{O}_{3}+\mathrm{h} v(\lambda<411 \mathrm{~nm}) \rightarrow \mathrm{O}\left({ }^{1} \mathrm{D}\right)+\mathrm{O}_{2}\left(\mathrm{X}^{3} \Sigma_{g}{ }^{-}\right) \\
& \mathrm{O}_{3}+\mathrm{h} v(\lambda<310 \mathrm{~nm}) \rightarrow \mathrm{O}\left({ }^{1} \mathrm{D}\right)+\mathrm{O}_{2}\left({ }^{1} \Delta_{g}\right)
\end{aligned}
$$

Photoexcitation in the Wulf band (9) produces triplet states of $\mathrm{O}_{3}$ that have energies more than $101.4 \mathrm{~kJ} / \mathrm{mol}$ $(1.051 \mathrm{eV})$. The existence of (rather) distinct absorption spectra actually shows that triplet state ozone molecules do not immediately fall apart. The vertical excitation energy of the triplet states ${ }^{3} \mathrm{~B}_{2},{ }^{3} \mathrm{~B}_{1}$, and ${ }^{3} \mathrm{~A}_{2}$ are $98.4,156.3$ and $170.8 \mathrm{~kJ} / \mathrm{mol}$ respectively. The radiative lifetimes (RLT) of the ${ }^{3} \mathrm{~B}_{2},{ }^{3} \mathrm{~A}_{2}$ and ${ }^{3} \mathrm{~B}_{1}$ states of ozone are $83.1 \mathrm{~s}, 0.038 \mathrm{~s}$ and $0.200 \mathrm{~s}$, respectively [47].

Photoexcitations in the Chappuis band $(10,11)$ produce singlet states of $\mathrm{O}_{3}$ with energies of more than $195.5 \mathrm{~kJ} / \mathrm{mol}$ $(2.026 \mathrm{eV})$ and of more than $258 \mathrm{~kJ} / \mathrm{mol}(2.678 \mathrm{eV})$, respectively. Photoexcitations in the Huggins (12) and Hartley bands (13) produce singlet states of $\mathrm{O}_{3}$ with energies of more than $291.0 \mathrm{~kJ} / \mathrm{mol}(3.016 \mathrm{eV})$ and 385.9 $\mathrm{kJ} / \mathrm{mol}(3.999 \mathrm{eV})$, respectively [45].

\subsubsection{Vibrationally Excited Ozone Molecules}

Ozone has three vibrational quantum numbers: $v_{1}$ for the symmetric stretch, $v_{2}$ for the bend and $v_{3}$ for the antisymmetric stretch. Theoretically, 185 energetically different vibrational states can be calculated up to the dissociation threshold [46].

Ozone absorbs thermal radiation at wavelengths of 9.065 , 9.596 and $14.267 \mu \mathrm{m}$, at which point the 3 lowest vibrational energy levels of ${ }^{16} \mathrm{O}_{3}$ are produced: $\mathrm{O}_{3}(1,0,0)=$ $1101.9 \mathrm{~cm}^{-1}(13.2 \mathrm{~kJ} / \mathrm{mol}), \mathrm{O}_{3}(0,1,0) 698.5 \mathrm{~cm}^{-1}(8.4$ $\mathrm{kJ} / \mathrm{mol})$ and $\mathrm{O}_{3}(0,0,1)=1043.9 \mathrm{~cm}^{-1}(12.5 \mathrm{~kJ} / \mathrm{mol})$, respectively [46]. The thermal wavelengths that $\mathrm{O}_{3}$ absorbs belong to the outgoing long-wave radiation (OLR) of Earth. It is likely that a considerable proportion of the stratospheric ozone is constantly in vibrationally excited states, except above the poles.

\subsubsection{Self-decay of Ozone}

In technological applications such as wastewater disinfection technology, the temperature-dependent half-life time (HLT) of ozone is well realized [48]. In the air the HLT of ozone is about 3 months at $-50^{\circ} \mathrm{C}, 18$ days at $-35^{\circ} \mathrm{C}$ and 8 days at $-25^{\circ} \mathrm{C}$ [49].

It has been shown that the decay of ozone follows an empirical mathematical formula. This formula is used to calculate the optimum time intervals when to prepare ozone for a technological application [50].

It has been suggested that collisions with other molecules (bimolecular mechanism) cause the self-decay. The kinetic energy per kelvin (monatomic ideal gas) is $\mathrm{KE}_{\text {avg }}=3 \times[\mathrm{R} / 2]=3 \mathrm{R} / 2$; per mole it is $3.46 \mathrm{~kJ} / \mathrm{mol}$ at $273 \mathrm{~K}$ [51]. It can be approximated that at $185 \mathrm{~K}$ one mole of ozone is receiving in collisions about $2 \mathrm{~kJ}$ of kinetic energy.

Another possibility for self-decay is a unimolecular mechanism via the absorption of thermal radiation. In both cases the acquired energy is a function of temperature. Depending on the temperature, the absorption of thermal radiation may be more important than kinetic collisions in the self-decay of ozone

\subsection{Photoexcitation of $\mathrm{O}_{2}\left(\mathrm{X}^{3} \Sigma_{\mathrm{g}}^{-}\right)$to Excited Oxygen Molecules}

Vibrationally or electronically excited $\mathrm{O}_{2}$ molecules may undergo reactions that are slow or impossible for ground state $\mathrm{O}_{2}$ molecules. Within its dissociation range, $\mathrm{O}_{2}\left(\mathrm{X}^{3} \Sigma_{\mathrm{g}}{ }^{-}\right)$has up to 26 different vibrational states $\left(v_{1}-v_{26}\right)$. Energy content of each $v_{\mathrm{i}}$ (cumulatively) increases by18.6 to $16.4 \mathrm{~kJ} / \mathrm{mol}$. Below its ionization threshold, $\mathrm{O}_{2}$ has several electronically excited states [7]. Each of these states has individual dissociation ranges within which they have individual vibrationally energy levels as well. Table 1 presents the parameters of those electronically excited $\mathrm{O}_{2}$ molecules which have importance in the stratosphere. Additionally, are presented the parameters of $\mathrm{O}_{2}\left(\mathrm{~B}^{3} \Sigma_{\mathrm{u}}\right)$ and $\mathrm{O}_{2}\left({ }^{3} \Pi_{\mathrm{u}}\right.$ molecules, which are photoexcited in the MLT ozone layer as well as above it [52].

The RLT of $\mathrm{O}_{2}\left({ }^{1} \Delta_{\mathrm{g}}\right)$ in the air is 75 minutes. It is relatively immune to deactivation by atmospheric gases [53], and so it is an effective reactant whenever formed in the atmosphere. $\mathrm{O}_{2}\left(\mathrm{a}^{1} \Delta_{\mathrm{g}}\right)$ and $\mathrm{O}_{2}\left(\mathrm{~b}^{1} \Sigma_{\mathrm{g}}{ }^{+}\right)$states are known to form indirectly via various sensitizer systems [54]. $\mathrm{O}_{2}$ $\left(a^{1} \Delta_{g}\right)$ produced via photoexcitation is planned to be utilized as booster in combustion technology [55]. The fluorescence emission of $\mathrm{O}_{2}\left(\mathrm{a}^{1} \Delta_{\mathrm{g}} \rightarrow \mathrm{X}^{3} \Sigma_{\mathrm{g}}{ }^{-}\right)$produces the IR atmospheric nightglow system at $1.27 \mu \mathrm{m}$, and that of $\mathrm{O}_{2}\left(\mathrm{~b}^{1} \Sigma_{\mathrm{g}}^{+} \rightarrow \mathrm{X}^{3} \Sigma_{\mathrm{g}}^{-}\right)$produces the atmospheric nightglow system at $761.9 \mathrm{~nm}$. 
Table 1. Excitation Energies and Enthalpies of Oxygen Molecules at Different Electronic States [6, 7]

\begin{tabular}{|l|l|l|l|}
\hline $\mathrm{O}_{2}$ molecule & $\begin{array}{l}\text { Excitation energy } \\
\mathrm{kJ} / \mathrm{mol}\end{array}$ & Excitation wavelength (nm) & Dissociation range $\mathrm{kJ} / \mathrm{mol}$ \\
\hline $\mathrm{X}^{3} \Sigma_{\mathrm{g}}-$ & 0 & & 493.7 \\
\hline $\mathrm{a}^{1} \Delta_{\mathrm{g}}$ & 94.3 & 1269 & 399.4 \\
\hline & 112.3 & 1065 & \\
$\mathrm{~b}^{1} \Sigma_{\mathrm{g}}^{+}$ & 157.0 & A band: center at $762 \mathrm{~nm}$ & 336.7 \\
& 173.4 & B band: center at $690 \mathrm{~nm}$ & \\
\hline $\mathrm{c}^{1} \Sigma_{\mathrm{u}}-\mathrm{A}^{\prime 1} \Delta_{\mathrm{u}}$ & 189,9 & $\Upsilon$ band: center at $630 \mathrm{~nm}$ & 102.9 \\
$\mathrm{~A}^{3} \Sigma_{\mathrm{u}}^{+}$ & 390.8 & $243<\lambda<252$ & 83.0 \\
\hline $\mathrm{B}^{3} \Sigma_{\mathrm{u}}^{-}$ & 410.6 & $243<\lambda<252$ & 74.8 \\
\hline${ }^{3} \Pi_{\mathrm{u}}$ & 418.6 & $243<\lambda<252$ & 93.0 \\
\hline
\end{tabular}

In the atmosphere ground state $\mathrm{O}_{2}$ molecules are photoexcited to $\mathrm{O}_{2}\left(\mathrm{a}^{1} \Delta_{\mathrm{g}}, \mathrm{v}=0\right.$ and 1$)$ by IR photons (14) (see Table 1).

$$
\mathrm{O}_{2}\left(\mathrm{X}^{3} \Sigma_{\mathrm{g}}{ }^{-}\right)+\mathrm{h} v(\lambda=1060 \mathrm{~nm}) \rightarrow \mathrm{O}_{2}\left(\mathrm{a}^{1} \Delta_{g}, \mathrm{v}=0\right)
$$

Photoexcitation by red light photons produce $\mathrm{O}_{2}\left(\mathrm{~b}^{1} \Sigma_{\mathrm{g}}^{+}\right.$, $v=0,1$ and 2) (15).

$$
\mathrm{O}_{2}\left(\mathrm{X}^{3} \Sigma_{\mathrm{g}}{ }^{-}\right)+\mathrm{h} v(\lambda=760 \mathrm{~nm}) \rightarrow \mathrm{O}_{2}\left(\mathrm{~b}^{1} \Sigma_{\mathrm{g}}{ }^{+} \mathrm{v}=0\right)
$$

When $\mathrm{O}_{2}\left(\mathrm{X}^{3} \Sigma_{\mathrm{g}}{ }^{-}\right)$is photoexcited in the laboratory by UV photons between $243<\lambda<252 \mathrm{~nm}$ ), vibrationally excited states of $\mathrm{O}_{2}\left(\mathrm{c}^{1} \Sigma_{\mathrm{u}}^{-}, \mathrm{v}>12, \mathrm{~A}^{1} \Delta_{\mathrm{u}}, \mathrm{v}>8\right.$, and $\mathrm{A}^{3} \Sigma_{\mathrm{u}}^{+}$, $v>7)$ are produced $(16)[56,57]$.

$$
\mathrm{O}_{2}\left({ }^{3} \Sigma_{\mathrm{g}}^{-}\right)+\mathrm{hv}(243<\lambda<252 \mathrm{~nm}) \rightarrow \mathrm{O}_{2}\left(\mathrm{~A}^{3} \Sigma_{\mathrm{u}}^{+}\right)
$$

\subsection{Stratospheric Daytime Reactions}

\subsubsection{Photolysis of $\mathrm{O}_{3}$}

The photolysis of ozone (2) in the daytime stratosphere is actually comprised of five energetically different pathways (9) to (13). The most important of them is (13).

This reaction has been extensively studied. Measurements show that the reaction does not stop (i.e., its quantum yield does not go to 0 ) even at wavelengths as long as $330 \mathrm{~nm}$ if the temperature is cold enough [58]. This is due to the participation of vibrationally excited ozone molecules in the reaction. Owing to this there is a "tail," the contribution of which enhances the total integrated $\mathrm{O}\left({ }^{1} \mathrm{D}\right)$ production by more than one third.

\subsubsection{The Three-body Recombination}

Reaction (3) is the principal ozone-forming reaction at nearly all altitudes in the atmosphere. $M$ represents a non-reactive species, which take up the energy released in (3) to stabilize $\mathrm{O}_{3}$. Without its presence, the produced $\mathrm{O}_{3}$ would immediately return to its respective parts as $\mathrm{O}$ and $\mathrm{O}_{2}$.

If $\mathrm{O}_{2}\left(\mathrm{X}^{3} \Sigma_{\mathrm{g}}^{-}, \mathrm{v}=0\right)$ as $\mathrm{M}$ molecule receives the released energy, vibrationally excited ground state $\mathrm{O}_{2}$ molecules (up to the level $v=5)$ are produced. If the produced $\mathrm{O}_{2}\left(\mathrm{X}^{3} \Sigma_{\mathrm{g}}{ }^{-}, v\right.$ = 5) further reacts with $\mathrm{O}$ atoms and $\mathrm{M}$ is then $\mathrm{O}_{2}\left(\mathrm{~b}^{1} \Sigma_{\mathrm{g}}{ }^{+}\right)$, vibrationally excited ground state $\mathrm{O}_{2}$ molecules up to the level of $v \geq 18$ are produced. According to McGrath and Norrish [59], if (and when) the produced $\mathrm{O}_{2}\left(\mathrm{X}^{3} \Sigma_{\mathrm{g}}^{-}, v \geq 18\right)$ react with ozone, $\mathrm{O}\left({ }^{1} \mathrm{D}\right)$ will be produced.

$$
\mathrm{O}_{2}\left(\mathrm{X}^{3} \Sigma_{\mathrm{g}}^{-}, v \geq 18\right)+\mathrm{O}_{3} \rightarrow 2 \mathrm{O}_{2}\left(\mathrm{X}^{3} \Sigma_{\mathrm{g}}^{-}, v=0\right)+\mathrm{O}\left({ }^{1} \mathrm{D}\right)
$$

This energy pooling pathway may not be a frequent one, but even with a small probability it boosts the dynamics of the stratospheric ozone layer in terms of $\mathrm{O}\left({ }^{1} \mathrm{D}\right)$ production.

\subsubsection{Reactions of Singlet Oxygen Molecules with Ozone}

When reacting with ozone, singlet oxygen molecules produce $\mathrm{O}\left({ }^{3} \mathrm{P}\right)$ atom $(18,19)$.

$$
\begin{gathered}
\mathrm{O}_{2}\left({ }^{1} \Delta_{g}\right)+\mathrm{O}_{3}(1,0,0) \rightarrow \mathrm{O}\left({ }^{3} \mathrm{P}\right)+2 \mathrm{O}_{2}\left(\mathrm{X}^{3} \Sigma_{g}{ }^{-}\right) \\
\Delta \mathrm{H}^{\mathrm{o}}=-1.0 \mathrm{~kJ} / \mathrm{mol} \\
\mathrm{O}_{2}\left(\mathrm{~b}^{1} \Sigma_{\mathrm{g}}^{+}\right)+\mathrm{O}_{3} \rightarrow \mathrm{O}\left({ }^{3} \mathrm{P}\right)+2 \mathrm{O}_{2}\left(\mathrm{X}^{3} \Sigma_{g}{ }^{-}\right) \\
\Delta \mathrm{H}^{\mathrm{o}}=-47.5 \mathrm{~kJ} / \mathrm{mol}
\end{gathered}
$$

Reaction (19) is expected to be very efficient. An energy transfer process (20) is possible as well. Then excited $\mathrm{O}_{3} *$ molecule is formed [11].

$$
\mathrm{O}_{2}\left({ }^{1} \Delta_{g}\right)+\mathrm{O}_{3} \rightarrow \mathrm{O}_{2}\left(\mathrm{X}^{3} \Sigma_{g}\right)+\mathrm{O}_{3}{ }^{*}
$$

Singlet oxygen molecules maintain the stability of the stratospheric ozone layer. This is an important expansion of Chapman's theory of ozone.

3.6.4. Reactions Producing $\mathrm{O}_{2}\left(\mathrm{~b}^{1} \Sigma_{\mathrm{g}}^{+}\right)$in the Stratosphere

$\mathrm{O}_{2}\left(\mathrm{~b}^{1} \Sigma_{\mathrm{g}}^{+}\right)$is generated in the stratosphere when $\mathrm{O}_{2}$ $\left(\mathrm{A}^{3} \Sigma_{\mathrm{u}}^{+}\right)$relaxes $(21)[60,61]$.

$$
\mathrm{O}_{2}\left(\mathrm{~A}^{3} \Sigma_{\mathrm{u}}^{+}\right) \rightarrow \mathrm{O}_{2}\left(\mathrm{~b}^{1} \Sigma_{\mathrm{g}}^{+}\right)+\mathrm{h} v
$$

The three-body reaction (22), an energy transfer via $\mathrm{O}\left({ }^{1} \mathrm{D}\right)$ to $\mathrm{O}_{2}$, is an important source of $\mathrm{O}_{2}\left(\mathrm{~b}^{1} \Sigma_{\mathrm{g}}{ }^{+}\right)$at vibrational levels $v=0$ and 1 in Earth's atmosphere [62].

$\mathrm{O}\left({ }^{1} \mathrm{D}\right)+\mathrm{O}_{2}\left(\mathrm{X}^{3} \Sigma_{\mathrm{g}}{ }^{-}\right)+\mathrm{M} \rightarrow \mathrm{O}_{2}\left(\mathrm{~b}^{1} \Sigma_{\mathrm{g}}{ }^{+}\right)+\mathrm{O}\left({ }^{3} \mathrm{P}\right)+\mathrm{M}$;

$$
\Delta \mathrm{H}^{0}=-32.7 \mathrm{~kJ} / \mathrm{mol}
$$

Wayne [63] suggested that $\mathrm{O}_{2}\left(\mathrm{~b}^{1} \Sigma_{g}^{+}\right)$is formed in the energy-pooling process of two $\mathrm{O}_{2}\left({ }^{1} \Delta_{g}\right)$. Then $\mathrm{O}_{2}\left(\mathrm{~b}^{1} \Sigma_{\mathrm{g}}^{+}\right)$is 
preferentially formed with two quanta of vibrational excitation (23) [64]:

$$
\begin{gathered}
\mathrm{O}_{2}\left({ }^{1} \Delta_{g}, v=1\right)+\mathrm{O}_{2}\left({ }^{1} \Delta_{g} v=1\right) \rightarrow \mathrm{O}_{2}\left(\mathrm{~b}^{1} \Sigma_{g}{ }^{+} v=2\right) \\
+\mathrm{O}_{2}\left(\mathrm{X}^{3} \Sigma_{g}{ }^{-}\right) ; \Delta \mathrm{H}^{0}=-34.3 \mathrm{~kJ} / \mathrm{mol}
\end{gathered}
$$

At an altitude of 45 to $48 \mathrm{~km}$ the dissociation rate of the $\mathrm{O}_{2}$ by UV, the production rates of $\mathrm{O}\left({ }^{1} \mathrm{D}\right), \mathrm{O}_{2}\left({ }^{1} \Delta_{g}\right)$ and $\mathrm{O}_{2}\left(\mathrm{~b}^{1} \Sigma_{g}^{+}\right)$via the reactions (10) to (13) are the highest [42].

\subsection{The Ablation of Meteoroids: An Important Source of Energy for the Nightglows}

Important nightglows in the upper atmosphere are the

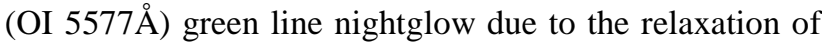
$\mathrm{O}\left({ }^{1} \mathrm{~S}\right)$ to $\mathrm{O}\left({ }^{1} \mathrm{D}\right)$ and the UV nightglows due to the relaxation of $\mathrm{O}_{2}\left(\mathrm{c}^{1} \Sigma_{\mathrm{u}}^{-}, \mathrm{A}^{, 1} \Delta_{\mathrm{u}}\right.$, and $\left.\mathrm{A}^{3} \Sigma_{\mathrm{u}}{ }^{+}\right)$to ground state $\mathrm{O}_{2}$ molecules. A long-term puzzle in aeronomy has been the energy sources of the nightglows. Energy generated via the ablation of meteoroids may be an important missing link.

\subsubsection{The Frequency of Impacts and Elevation of Maximum Ablation}

Based on the measurements of cosmic-enriched elements (Ir, Pt, Os and super-paramagnetic Fe) in polar ice cores and deep-sea sediments, the daily accumulation rates of interplanetary dust particles on Earth ranges from 100 to 300 tons [65]. Meteoroids entering at cosmic speed start to ablate due to atmospheric friction. Temperatures may rise even to $3500^{\circ} \mathrm{C}$ for several seconds [66].

The ablation profiles of individual elements differ from each other. The maximum ablation of iron takes place between 95 and $85 \mathrm{~km}$ at temperatures of 2000 to $2300 \mathrm{~K}$ [67]. During ablations so much energy is generated that the $4.3 \mu \mathrm{m}$ thermal radiance at an altitude of $92 \mathrm{~km}$ is enhanced by about a factor of 50 compared to the $4.3 \mu \mathrm{m}$ radiation due to the auroral activity [68].

The overall influx of meteoroids to Earth is constant, but on a day-to-day basis the frequency of impacts at a certain latitudinal and longitudinal location changes randomly.

\subsubsection{Chemical Reactions Inflicted by Frictional Heat Generated during Ablation}

Any reaction involving molecular oxygen could, in principle, lead to the formation of excited oxygen molecules if sufficient energy were liberated [69]. Heat generated during the ablation of meteoroids is able to produce a wide array of excited oxygen molecules starting from highly excited $\mathrm{O}_{2}$ molecules, such as $\mathrm{O}_{2}\left({ }^{3} \Pi_{u}\right)$, and ending in the lowest energy states of $\mathrm{O}_{2}\left(\mathrm{~b}^{1} \Sigma_{\mathrm{g}}{ }^{+}\right)$and $\mathrm{O}_{2}\left(\mathrm{a}^{1} \Delta_{\mathrm{g}}\right)$. According to observations, the UV nightglow due to $\mathrm{O}_{2}\left(\mathrm{~A}^{3} \Sigma_{\mathrm{u}}{ }^{+}\right)$is strongest at 90 to $100 \mathrm{~km}[70,71]$. It is likely that energy derived from ablations in the MLT layer is producing $\mathrm{O}_{2}\left(\mathrm{c}^{1} \Sigma_{\mathrm{u}}^{-}, \mathrm{A}^{, 1} \Delta_{\mathrm{u}}\right.$ and $\left.\mathrm{A}^{3} \Sigma_{\mathrm{u}}^{+}\right)$which further fuel the UV nightglows.

At temperatures over $2000 \mathrm{~K}$, iron abstracts $\mathrm{O}$ atoms from $\mathrm{O}_{2}$ molecules, and excited $\mathrm{O}\left({ }^{1} \mathrm{~S}\right)$ and $\mathrm{O}\left({ }^{1} \mathrm{D}\right)$ atoms are then produced. Due to the low overall concentration of iron in meteoroids, the production of $\mathrm{O}\left({ }^{1} \mathrm{~S}\right)$ via this pathway is probably rather small.

The shock-heating over $3500 \mathrm{~K}$ excites $\mathrm{N}_{2}$ molecules even to the states of $\mathrm{N}_{2}\left(\mathrm{~b}^{, 1} \Sigma_{\mathrm{u}}^{+}\right)(12.575 \mathrm{eV})$ and $\mathrm{N}_{2}\left(\mathrm{~b}^{1} \Pi_{\mathrm{u}}\right)$ $(12.849 \mathrm{eV})$ [72]. It is reasonable to presume that the normal ablation temperature of 2000 to $2300 \mathrm{~K}$ would produce excited (metastable) $\mathrm{N}_{2}\left(\mathrm{~A}^{3} \Sigma^{+}{ }_{\mathrm{u}}\right)$, the energy content of which is $9.67 \mathrm{eV}$. The quenching of $\mathrm{N}_{2}\left(\mathrm{~A}^{3} \Sigma^{+}{ }_{\mathrm{u}}\right)$ by $\mathrm{O}\left({ }^{3} \mathrm{P}\right)$ atoms produces $\mathrm{O}\left({ }^{1} \mathrm{~S}\right)(24)[73]$.

$$
\begin{gathered}
\mathrm{N}_{2}\left(\mathrm{~A}^{3} \Sigma_{\mathrm{u}}^{+}\right)+\mathrm{O}\left({ }^{3} \mathrm{P}\right) \rightarrow \mathrm{N}_{2}+\mathrm{O}\left({ }^{1} \mathrm{~S}\right) ; \\
\Delta \mathrm{H}^{0}=-529.3 \mathrm{~kJ} / \mathrm{mol}
\end{gathered}
$$

Measurements during rocket-borne experiments [68] showed that in one leg the emission intensity of the green line nightglow was 10 kilorayleigh (kR), but in another leg it was $30 \mathrm{kR}$. This kind of variation implies a correlation between $\mathrm{O}\left({ }^{1} \mathrm{~S}\right)$ production and the frequency of meteoroid impacts.

Considering the high proportion of $\mathrm{N}_{2}$ in the air, (24) is an important pathway to produce $\mathrm{O}\left({ }^{1} \mathrm{~S}\right)$ in the night sky at the altitudes of 90 to $100 \mathrm{~km}$ to fuel the green nightglow.

\subsection{Factors Affecting Stratospheric Night-time Reactions}

Astronomical dusk/dawn is divided into civil, nautical and astronomical twilights. At the Equator on the ground, their total duration is $2 \mathrm{~h} 20 \mathrm{~min}$ [74]. Due to the altitude, the sunset is later (sunrise earlier) by 1 minute for every $1.5 \mathrm{~km}$ rise, approximately linearly regardless of latitude [75]. For this reason, the dusk and dawn at $20 \mathrm{~km}$ lasts about $2 \mathrm{~h} 33 \mathrm{~min}$ and at $50 \mathrm{~km}$ about $2 \mathrm{~h} 53 \mathrm{~min}$, a difference of about 3.5\%.

During the dusk and dawn, the stratosphere receives visible and IR light from the sun and also from the moon, stars and auroras for production of singlet oxygens and triplet state ozone molecules. Complete darkness or astronomical night is the period between astronomical dusk and dawn [76]. At the Equator at $20 \mathrm{~km}$ it lasts about $9 \mathrm{~h} 27$ min, and at $50 \mathrm{~km}$ about $9 \mathrm{~h} 7 \mathrm{~min}$. Then only light from nightglows, moon, auroras and the stars is available. The amount of UV, visible and IR light dramatically decreases. The OLR is an altitude dependent stable source of energy throughout the night.

Moving upwards in the stratosphere the length of the darkness decreases, the intensity of the OLR decreases [68], and the intensity of the light from nightglows, stars and auroras increases. These factors more or less balance the supply of energy, so the stratospheric night-time temperature falls only 1 to 2 degrees between the altitudes of 20 to $48 \mathrm{~km}$.

\subsection{Ozone Depletion above the Arctic and Antarctica}

The ozone depletion is more severe in the Antarctica than in the Arctic (see Figure 7). 


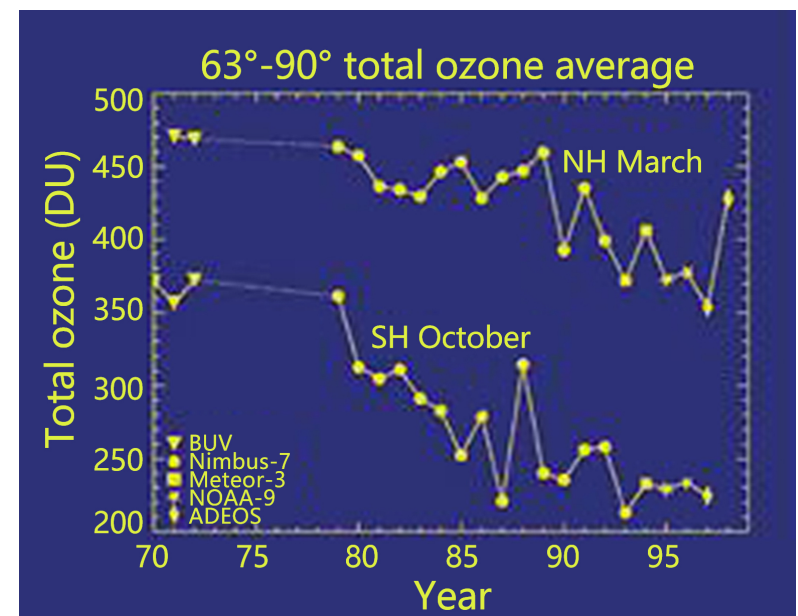

Figure 7. The Total Column of Ozone is Shown for the Arctic (NH, top) and the Antarctica (SH, bottom) [77]

\subsubsection{Effect of Coldness and the Self-decay of Ozone in Ozone Depletion}

The density of ozone is $2.11 \mathrm{~g} / \mathrm{cm}^{3}$. Its specific gravity is 1.660 when that of the air is 1.000 [78]. Ozone has no buoyancy anywhere in the atmosphere, so immediately after formation it starts to descend.

It is known that heavy ozone ${ }^{50} \mathrm{O}_{3}\left({ }^{16} \mathrm{O}^{18} \mathrm{O}^{16} \mathrm{O}\right)$ enriches in the troposphere and lower stratosphere [79]. The descent of ozone is a likely reason for that. Given that in the stratosphere, ozone descends $20 \mathrm{~m}$ per day, during the 4 to 6 months of winter it would descend by 2.4 to $3.6 \mathrm{~km}$. In the absence of ozone-producing mechanisms the ozone density then decreases in the lower stratosphere.

The average winter temperature in the Arctic (at $30 \mathrm{hPA}$ or $24.5 \mathrm{~km}$ ) is $-70{ }^{\circ} \mathrm{C}$ [80] and in Antarctica (at $46 \mathrm{hPa}$ or $21 \mathrm{~km})$ it is $-90^{\circ} \mathrm{C}$ [81]. According to Charles's law [82], the volume of a fixed mass of dry gas decreases by $1 / 273$ times the volume at $0{ }^{\circ} \mathrm{C}$ for every $1{ }^{\circ} \mathrm{C}$ fall in temperature. At $-90^{\circ} \mathrm{C}$, the decrease in volume is $33 \%$ and at $-70^{\circ} \mathrm{C}$ it is $25 \%$. The same amount of ozone in moles in a smaller volume means a greater density of ozone. The speed of descent of ozone molecules is greater in Antarctica than it is in the Arctic.

In the Arctic at $-70{ }^{\circ} \mathrm{C}$ the HLT of ozone would be something like 62 months, the loss of ozone during the winter would be about $6 / 62 \times 100 \%=10 \%$. In the Antarctica, at $-90^{\circ} \mathrm{C}$, the HLT of ozone would be about 120 months, and the loss of ozone would be about $6 / 120 \times 100=5 \%$.

Ozone depletion occurs due to the combined effect of the descent of ozone due to gravity (the physical reason) and the self-decay of ozone (the chemical reason). Because ozone depletion is more severe in the Antarctica than it is in the Arctic, the descent of ozone is a more important factor than its self-decay. During the spring when sunshine reaches the polar areas, the ozone layer is recovered.

\subsubsection{Lagging of Air Molecules Relative to the Ground on the Rotating Earth}

The amount of torque needed to cause any given angular acceleration is proportional to the moment of inertia of a body. It can be thought of as a physical "property" of an object, similar to that of mass [83]. The moment of inertia of Earth's atmosphere is lower than that of its solid body. Due to this lower angular velocity, the atmosphere does not follow the speed of the solid body while spinning. In other words, the air is lagging. The mass of the atmosphere decreases strongly when moving upwards in the atmosphere. The higher the altitude, the more the air lags. This creates a vertical factor in the lagging of the air relative to the surface.

At the Equator, the rotational speed of Earth is $464 \mathrm{~m} / \mathrm{s}$, and at the poles it is $0 \mathrm{~m} / \mathrm{s}$. The rotational speed varies according to the cosine of the latitude [84]. At $89^{\circ} \mathrm{N}$ it is $8.1 \mathrm{~m} / \mathrm{s}$, and at $80^{\circ} \mathrm{N}$ it is $80.5 \mathrm{~m} / \mathrm{s}$. The lower the latitude, the greater the lag of air. This creates a horizontal (latitudinal) factor in the lagging of the air relative to the ground.

Due to the vertical lagging, noctilucent clouds seem to move anticlockwise. However, in fact they are moving clockwise but at a lower speed than the observer on the ground. Due to the combined horizontal and vertical lagging of air, fast moving meteorites seem to create twisted trails. These observations are generally interpreted as winds in the upper atmosphere, even though there are no known and experimentally proven physical factors to generate horizontal winds at those altitudes.

Helium, generated below the ground, moves upwards regardless of the atmospheric pressure or temperature, while ozone descends. These movements (flows or tides) can be interpreted as vertical winds in the upper atmosphere. Due to the lagging of air, this movement creates the illusion of a polar vortex with seemingly faster moving edges and a slower moving center.

\subsection{Practical Examples of the Intensity of Ozone Turnover}

Above Germany during winter nights, the stratospheric temperature at an altitude of $30 \mathrm{~km}$ is even 25 degrees less than during the summer nights (see Figure 8). In the stratopause the difference is only about 10 degrees [39].

In Germany snow covered soil radiates during winter less OLR than during summer. Subsequently at $30 \mathrm{~km}$ the OLR absorption by $\mathrm{O}_{3}$ then decreases. The self-decay of $\mathrm{O}_{3}$, and the rate of ozone turnover decreases. This leads to colder winter temperature. Moving to the stratopause the absorption of IR, VIS and UV radiation from nightglows, stars, the moon and auroras by $\mathrm{O}_{3}$ gain more importance. Temperature difference between winter and summer is smaller. 

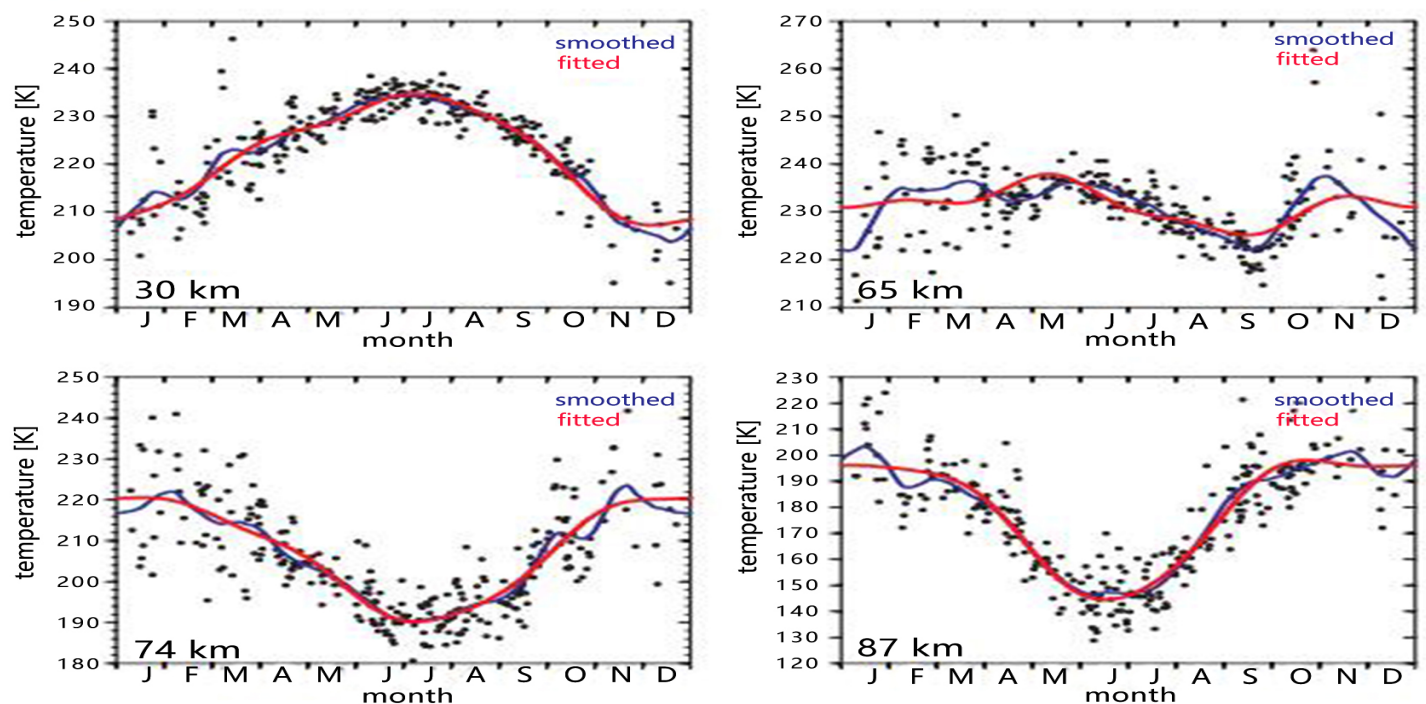

Figure 8. Seasonal temperature (average June 2002 to July 2007) variation at an altitude of $30 \mathrm{~km}$. Black dots: nightly mean temperatures, blue line: filtered with \pm 30 day Hanning window, red line: harmonic fit [39]

During the winter months, at altitudes of $74 \mathrm{~km}$ and $87 \mathrm{~km}$, the maximum temperature is even 25 degrees higher than in the summer months (see Figure 8). In winter the lower boundary of the MLT ozone layer extends below $87 \mathrm{~km}$ and the MMM ozone layer is then formed at altitudes of 70 to $75 \mathrm{~km}$ between 45 to $75^{\circ} \mathrm{N}$ [86]. (See Figure 9) The ozone turnover in these two ozone layers warms the altitudes of $74 \mathrm{~km}$ and $87 \mathrm{~km}$ in the winter but not in the summer.
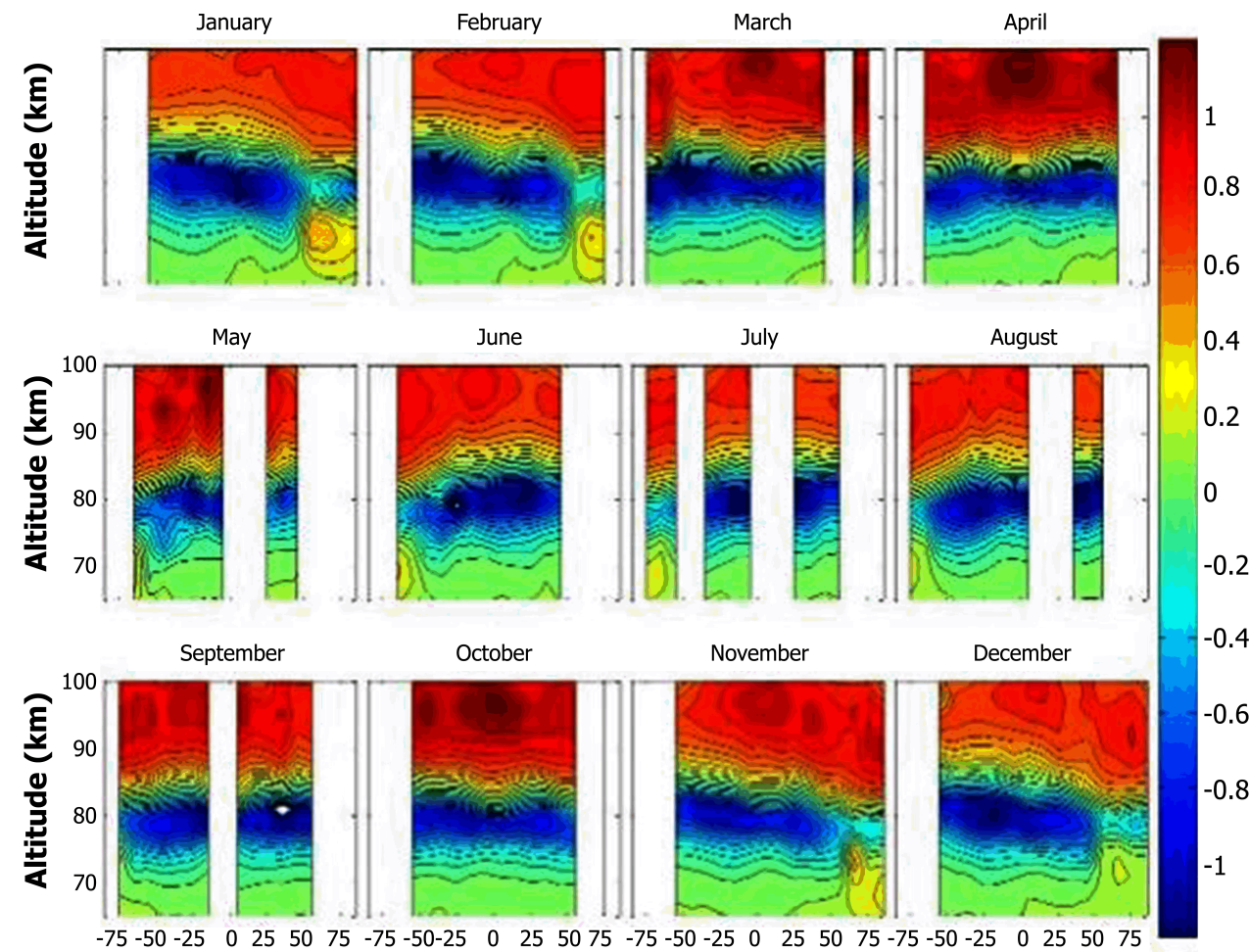

December

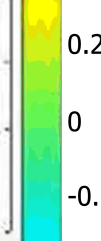

Latitude

Latitude

Latitude

Latitude

Figure 9. Seasonal change of lower boundary of MLT ozone layer during the year, and the occurrence of MMM ozone layer in November to February in the midlatitudes of the Northern Hemisphere (Mesosphere: $\log _{10} \mathrm{O}_{3}$ mixing ratio in 2003) [85] 


\section{Conclusions}

Ozone absorbs OLR, so most of the atmospheric ozone may constantly be in vibrationally excited states, except above the poles. In addition to the thermal absorption, ozone gains energy via kinetic collisions. Due to these phenomena, ozone is a labile molecule with a distinct temperature-dependent half-life time, and which is ultimately predestined to self-decay.

The existence of ozone in the atmosphere thus needs its constant reformation. The places of most intensive reformation are called ozone layers. There are two global ozone layers, the mesospheric-lower thermosphere (MLT) ozone layer at around 87 to $97 \mathrm{~km}$ and the stratospheric ozone layer at around 20 to $50 \mathrm{~km}$. The middle mesospheric ozone maximum (MMM) is formed in the wintertime at an altitude of 70 to $75 \mathrm{~km}$. Its location is restricted between the northern mid-latitudes and somewhat north from the Arctic Circle, and symmetrically in the Southern hemisphere.

Excited $\mathrm{O}_{2}\left(\mathrm{a}^{1} \Delta_{\mathrm{g}}\right)$ and $\mathrm{O}_{2}\left(\mathrm{~b}^{1} \Sigma_{g}^{+}\right)$are produced in the stratosphere via photoexcitation of red light and IR photons as well as via chemical reactions. At night, the intensity of their production is, of course, much lower. These singlet $\mathrm{O}_{2}$ molecules produce $\mathrm{O}\left({ }^{3} \mathrm{P}\right)$ when reacting with ozone. They tend to maintain the prevailing ozone concentration and provide stability to the ozone layer.

In the daytime at altitudes of 45 to $48 \mathrm{~km}, \mathrm{O}\left({ }^{1} \mathrm{D}\right), \mathrm{O}_{2}$ $\left(\mathrm{a}^{1} \Delta_{\mathrm{g}}\right)$ and $\mathrm{O}_{2}\left(\mathrm{~b}^{1} \Sigma_{\mathrm{g}}^{+}\right)$reach their maximum stratospheric concentrations. The ozone turnover as well as the released energy here are both high, which is manifested as the maximum stratospheric temperature between those altitudes.

The density of ozone is $60 \%$ more than that of the ambient air. Ozone has no buoyancy in the air and that is why the $\mathrm{O}_{3}$ molecules start to descend immediately when formed. In the 1930s, Chapman calculated that ozone in the stratosphere would descend $20 \mathrm{~m}$ per day. At the poles, therefore, ozone descends between 2.4 and $3.6 \mathrm{~km}$ during the winter.

Coldness increases the density of $\mathrm{O}_{3}$ relative to the ambient air. Antarctica is clearly colder than the Arctic, so the down drifting of $\mathrm{O}_{3}$ is greater in Antarctica than it is in the Arctic. The descent is the main cause for the depletion of stratospheric ozone above the poles during winter. During the spring when sunshine reaches the polar areas, the ozone layer is recovered.

\section{Acknowledgements}

I am very grateful to Matthew Wuethrich from the University of Jyväskylä Language Services for revising the English of the manuscript. I thank my wife Ritva for her support.

\section{REFERENCES}

[1] S. Newcomb, A rude attempt to determine the total light of all the stars, Astrophysical Journal, Vol. 14, 297-312, 1901.

[2] V. Yu. Khomich, A. I. Semenov and N. N. Shefov, Airglow as an Indicator of Upper Atmospheric Structure and Dynamics, 2008 Springer-Verlag Berlin Heidelberg. ISBN: 978-3-540-75832-7.

[3] M. Kasha, Introductory Remarks: The Renascence of Research on Singlet Oxygen, In: H. H. Wasserman and R. W. Murray (Eds), Singlet Oxygen, Organic Chemistry A Series of Monographs Vol. 40, Academic Press, New York, 1979. ISBN: 0-12-736650-4.

[4] G. Herzberg, Ein neuartiges “verbotenes” Absorptions banden system des $\mathrm{O}_{2}$ Moleküls, Naturwissenschaften, Vol. 32, 577, 1932.

[5] H. Kautsky, Quenching of luminescence by oxygen, Transactions of the Faraday Society, Vol 35, 216-219, 1939.

[6] T. G. Slanger and R. C. Copeland, Energetic Oxygen in the Upper Atmosphere and the Laboratory, Chemical Reviews, Vol. 103, No. 12, 4731-4766, 2003. DOI: $10.1021 /$ cr0205311.

[7] P. H. Krupenie, The Spectrum of Molecular Oxygen, Journal of Physical Chemistry Reference Data, Vol. 1, No. 2, 423534, 1972.

[8] S. Chapman, A Theory of Upper Atmospheric Ozone, Memoirs of the Royal Meteorological Society, Vol 3, 103125, 1930.

[9] J. T. N. Jones, Oxygen Chemistry, 211-218, In: B. M. McCormac (Ed), Atmospheres of Earth and Planets, D. Reidel Publishing Co., Dodrecht, Holland, 1975. ISBN: 90-277-0575-5.

[10] https://www.lenntech.com/library/ozone/decomposition/ozo ne-decomposition.htm.

[11] P. J. Hay, T. H. Dunning and W. A. Goddard III, Theoretical evidence for bound electronic excited states of ozone, Chemical Physical Letters, Vol. 23, No. 4, 457-462, 1973.1973. https://doi.org/10.1016/0009-2614(73)89001-3

[12] W. F. J. Evans and E. J. Llewellyn, Measurements of mesospheric ozone from observations of the $1.27 \mu$ band, Radio Science, Vol. 7, 45-50, 1972.

[13] P. B. Hays and R. G. Roble, Observation of mesospheric ozone at low latitudes, Planetary and Space Science, Vol. 21, 273-279, 1973.

[14] D. E. Miller and P. Ryder, Measurement of the ozone concentration from 55 to $95 \mathrm{~km}$ at sunset, Planetary and Space Science, Vol. 21, 963-970, 1973.

[15] D. Marsh, A. Smith, G. Brasseur, M. Kaufmann and K. Grossmann, The existence of a tertiary ozone maximum in the high-latitude middle mesosphere, Geophysical Research Letters, Vol. 28, No. 24, 4531-4534, 2001. 
[16] G. Megie, Ozon. Atmosphäre aus dem Gleichgewicht, p. 47. Springer-Verlag, Berlin 1989. ISBN: 3-540-5216-9.

[17]M. Allen and M. L. Delitsky, A Test of Odd-oxygen Photochemistry Using Spacelab 3 Atmospheric Trace Molecule Observations, Journal of. Geophysical, Research, 96, 12883 -12891, 1991. https://doi.org/10.1029/91JD002 30 .

[18] J. Eluszkiewic and M. Allen, A Global Analysis of the Ozone Deficit in the Upper and Lower Mesosphere, Journal of Geophysical Research, Vol. 98, 1069-1082, 1993.

[19] http://www.mitosyfraudes.org/Ingles/Crista.html.

[20]A. Anduaga, Sydney Chapman on the Layering of the Atmosphere: Conceptual Unity and the Modelling of the Ionosphere. Annals of Science, Vol. 66, No. 3, 333-344, 2009. https://doi.org/10.1080/00033790802329455

[21] G. W. van Loon and S. J. Duffy, Environmental Chemistry A Global Perspective, Oxford University Press, 49-50, 2005. DOI: 10.1016/0021-9169(72)90061-X

[22] B. J. Finlayson-Pitts and J. R. Pitts Jr. Chemistry of the Upper and Lower Atmosphere, Academic Press, p. 54 and p. 943, 2000

[23] R. E. Huffman, Atmospheric Ultraviolet Remote sensing, Academic Press, NY, 1992. ISBN: 0-12-360390-0.

[24] E. D. Lombardini, M. E. Pacheco-Thompson and M. A. Melanson, Radiation and Other Physical Agents, Volume II, Chapter 44, Pages 1421-1503, 2013, In: Haschek and Rousseaux's Handbook of Toxicological Pathology. ISBN: 978-0-12-415763-7.

[25] P. K. Carroll, R. E. Huffman, J. C. Larrabee and Y. Tanaka, Absorption by Atomic Nitrogen in the Extreme Ultraviolet, Astrophysical Journal, Vol 146, No. 2, 553-557, 1966.

[26] M. O. Vieitez, T. I. Ivanov, W. Ubachs, B. R. Lewis and C. A. de Lange, On the complexity of the absorption spectrum of molecular nitrogen, Journal of Molecular Liquids Vol. 141, 110-117, 2008. DOI: 10.1016/j.molliq.2008.01.014.

[27] R. E. Huffman, J. C. Larrabee and Y. Tanaka, New Absorption Spectra of Atomic and Molecular Oxygen in the Vacuum Ultraviolet. I. Rydberg Series from O I Ground State and New Excited $\mathrm{O}_{2}$ Bands, The Journal of Chemical Physics, Vol. 46, 2213, 1967.https://doi.org/10.1063/1.184 1026.

[28] S. J. Tu and J. B. Nee, Absorption spectrum of ozone in the 100-200 nm wavelength region, Surface Review and Letters, Vol. 9, 125-128, 2002.

[29] V. Gorshelev, A. Serdyuchenko, M. Weber, W. Chehade, and J. P. Burrows. High spectral resolution ozone absorption cross-sections - Part 1: Measurements, data analysis and comparison with previous measurements around $293 \mathrm{~K}$, Atmospheric Measuring Techniques, Vol. 7, 609-624, 2014. DOI: 10.5194/amt-7-609-2014.

[30] C.R. Nowlan, C.T. McElroy and J.R. Drummond, Measurements of the $\mathrm{O}_{2}$ A- and B-bands for determining temperature and pressure profiles from ACE-MAESTRO: Forward model and retrieval algorithm Journal of Quantitative Spectroscopy \& Radiative Transfer Vol. 108 371-388, 2007. DOI: 10.1016/j.jqsrt.2007.06.006.
[31] K. M. Smith and D.A. Newnham, Near-infrared absorption cross-sections and integrated absorption intensities of molecular oxygen $\left(\mathrm{O}_{2}, \mathrm{O}_{2}-\mathrm{O}_{2}\right.$, and $\left.\mathrm{O}_{2}-\mathrm{N}_{2}\right)$, Journal of Geophysical Research, Vol. 105, 7383-7396, 2000.

[32] D. A. Newnham and J. Ballard, Visible absorption cross-sections and integrated absorption intensities of molecular oxygen $\left(\mathrm{O}_{2}\right.$ and $\left.\mathrm{O}_{4}\right)$, Journal of Geophysical Research, Vol. 103, No. D22, 28,801-28,816, 1998.

[33] J. L. Fox, Ion Chemistry, pp. 333-347. In: G. R. North, J. Pyle and F. Zhang (Eds), Encyclopedia of Atmospheric Sciences, Vol 1, 2015, Elsevier. ISBN: 978-0-12-382225-3.

[34] Light and the Optical Environment, Princeton University Press, http://assets.press.princeton.edu/chapters/s2_10281. pdf.webmaster@press.princeton.edu.

[35] http://earthobservatory.nasa.gov/Features/UVB/.

[36] G. Wypych (Ed), Handbook of UV Degradation and Stabilization, ChemTech Publishing, Toronto, 2015. ISBN: 978-1-895198-86-7.

[37] B. Geerts and E. Linacre, The height of the tropopause, 1997. http://www-das.uwyo.edu/ geerts/cwx/notes/chap01/tropo. html.

[38] H. Chandra, S. Sharma, Y. B. Acharya and A. Jayaraman, A Rayleigh lidar study of the atmospheric temperature structure over Mt. Abu, India, The Journal of Indian Geophysical Union, Vol. 9, No. 4, 279-298, 2005

[39] M. Gerding, J. Hoffner, J. Lautenbach, M. Rauthe, and F.-J. Lübken, Seasonal variation of nocturnal temperatures between 1 and $105 \mathrm{~km}$ altitude at $54^{\circ} \mathrm{N}$ observed by lidar, Atmospheric Chemistry and Physics, Vol. 8, 7465-7482, 2008. www.atmos-chem-phys.net/8/7465/2008/.

[40] F. T. Huang, R. D. Peters, P. K. Bhartia, H. G. Mayr, S. M. Frith, J. M. Russell III and M. G. Mlynczak, Temperature diurnal variations (migrating tides) in the stratosphere and lower mesosphere based on measurements from SABER on TIMED, Journal of Geophysical Research, Atmospheres, Vol. 115, No. D16121, 2010.https://doi.org/10.1029/2009J D013698.

[41] NPTL, Module I: Introduction to Meteorology and Oceanographia, Physics of Atmosphere and Ocean, Atmospheric Science, NPTL National Programme on Technology Enhanced Learning. https://nptel.ac.in/courses /119102007/.

[42] M. Nicolet, Aeronomic Reactions of hydrogen and ozone, pp. 1-51. In: G. Fiocco (Ed), Mesospheric Models and Related Experiments, D. Reidel, Dodrecht, Holland, 1971. ISBN: 90-154737.

[43] E. Kyrölä, J. Tamminen, G. W. Leppelmeier, V. Sofieva, S Hassinen, A. Seppala, P. T. Verronen, J. L. Bertaux, A. Hauchecorne, F. Dalaudier, D. Fussen, F. Vanhellemont, O. Fanton d'Andon, G. Barrot, A. Mangin, B. Theodore, M. Guirlet, R. Koopman, L. Saavedra de Miguel, P. Snoeij, T. Fehr, Y. Meijer, and R. Fraisse, Nighttime ozone profiles in the stratosphere and mesosphere by the Global Ozone Monitoring by Occultation of Stars on Envisat, Journal of Geophysical Research, Vol. 111, D24306, 2006. DOI: 10.1029/2006JD007193.

[44] A. Parrish, I. S. Boyd, G. E. Nedoluha, P. K. Bhartia, S. M. 
Frith, N. A. Kramarova, B. J. Connor, G. E. Bodeker, L. Froidevaux, M. Shiotani, and T. Sakazaki, Diurnal variations of stratospheric ozone measured by ground-based microwave remote sensing at the Mauna Loa NDACC site: measurement validation and GEOSCCM model comparison, Atmospheric Chemistry and Physics, Vol. 14, 7255-7272, 2014. https://doi.org/10.5194/acp-14-7255-20 14.

[45] S. Yu. Grebenshcikov, Z.-W. Qu, H. Zhue and R. Schinke, New theoretical investigations of the photodissociation of ozone in the Hartley, Huggins, Chappuis and Wulf bands, Physical Chemistry Chemical Physics, Vol. 9, 2044-2064, 2007.

[46] R. Siebert, P. Fleurat-Lessard, R. Schinke, M. Bittererova and S. C. Farantos, The vibrational energies of ozone up to the dissociation threshold: Dynamics calculations on an accurate potential energy surface, The Journal of Chemical Physics Vol. 116, No. 22, 9749-9767, 2002. https://doi.org/10.1063/1.1473664.

[47] H. Ågren, O. Vahtras and B. Minaev, Response Theory of Calculations of Spi-Orbit Coupling Phenomena in Molecules. In: P.-O. Löwdin, J. S. Sabin and M. C. Zerner (Eds), Advances in Quantum Chemistry, Vol. 27, p. 106, 1996. Academic Press. ISBN: 0-12-034827-6.

[48] D. McClurkin and D.E. Maier, Half-life time of ozone as a function of air conditions and movement, 10th International Working Conference on Stored Product Protection, Julius-Kühn-Archiv， 381-385， 425，2010. DOI: 10.5073/jka.2010.425.167.326.

[49] Ozone Data \& Conversion Tables, Plasma \& Reactive Gas Solutions. https://www.mksinst.com/docs/UR/astexozoned ata.pdf

[50] V. Gorshlev, Absorption spectroscopy of atmospheric species (ozone) https://www.msc-ep.uni-bremen.de/service s/lectures/practicals/pr_ozone_2016.pdf.

[51] https://en.wikipedia.org/wiki/Kinetic_theory_of_gases.

[52] K. Hänninen, The Role of Excited Oxygen Molecules in the Formation of the Secondary Ozone Layer at 87 to $97 \mathrm{~km}$, Environment and Ecology Research Vol. 1, 74-85, 2018. http://www.hrpub.org DOI: 10.13189/eer.2018.060107.

[53] R. P. Wayne, Reactions Involving Excited States of O and $\mathrm{O}_{2}$, pp. 125-132. In: B. M. McCormak (Ed), Physics and Chemistry of Upper Atmosphere, D. Reidel, Dodrecht, Holland, 1973. ISBN: 978-94-010-2542-3.

[54] M. E. Jimenez-Hernandez, F. Manjon, D. Garcia-Fresnadillo and G. Orellana, Solar Water disinfection by singlet oxygen molecule by singlet oxygen photogenerated with $\mathrm{Ru}(\mathrm{II})$ sensitizers, Solar Energy, Vol. 80, No 10, 1382-1387, 2006.

[55] A. M. Starik, Innovations in combustion technologies for propulsion $26^{\text {th }}$ International Congress of the Aeronautical Sciences, 2008 Central Institute of Aviation Motors, Moscow,

Russia. https://www.icas.org/media/pdf/ICAS\%20Congress\%20G eneral\%20Lectures/2008/ICAS\%202008\%20Starik.pdf.

[56] R. A. Copeland, K. Knutsen and T. G. Slanger. Using Laser-Induced Fluorescence to Study molecules of Atmospheric importance pp. 318-325. In: The Proceedings of the International Conference on Lasers '93- Lake Tahoe,
NV, 1993.

[57] R. A. Copeland, K. Knutsen, M. E. Onishi and T. Yalcin, Collisional removal of $\mathrm{O}_{2}\left(\mathrm{c}^{1} \Sigma_{\mathrm{u}}{ }^{-}, v=9\right)$ by $\mathrm{O}_{2}, \mathrm{~N}_{2}$ and $\mathrm{He}$, The Journal of Chemical Physics, Vol 105, No 23, 1034910355, 1996.

[58] Y. Matsumi, F. J. Comes, G. Hancock, A. Hofzumahaus, A. J. Hynes, M. Kawasaki, and A. R. Ravishankara, Quantum yields for production of $\mathrm{O}\left({ }^{1} \mathrm{D}\right)$ in the ultraviolet photolysis of ozone: Recommendation based on evaluation of laboratory data, Journal of Geophysical Research, Vol. 107, No. D3, ACH 1-1-ACH 1-12, 2002 https://doi.org/10.1029/2001JD000510.

[59] W. D. McGrath and R. G. W. Norrish, Production of Vibrationally Excited Oxygen Molecules in the Flash Photolysis of Ozone, Nature, Vol. 180, 1272-1273, 1957. DOI: $10.1038 / 1801272 b 0$.

[60] G. Bednarek, R. P. Wayne, J. Wildt, and E. H. Fink, Erratum, The yield of $\mathrm{O}_{2}\left(\mathrm{~b}^{1} \Sigma_{g}^{+}, v=0\right)$ produced by quenching of $\mathrm{O}_{2}\left(\mathrm{~A}^{3} \Sigma_{g}^{+}, v=8\right)$ by $\mathrm{O}_{2}$, [Chem. Phys., Vol. 185, 251-261, 1994], Chemical Physics, Vol. 222, 113-114, 1997.

[61] K. S. Kalogerakis, A. Totth, P. C. Cosby, T. G. Slanger and R. A. Copeland, Laboratory studies of the production of highly vibrationally excited $\mathrm{O}_{2}\left(\mathrm{a}^{1} \Delta_{\mathrm{g}}\right.$ and $\left.\mathrm{b}^{1} \Sigma_{q}^{+}\right)$from $\mathrm{O}_{2}\left(\mathrm{~A}^{3} \Sigma_{u}^{+}\right)$relaxation, EOS Transactions of the American Geophysical Union, Vol. 81, F944, 2000.

[62] A. Dušan, R. A. Pejaković, T. Copeland, G. Slanger and K. S. Kalogerakis: $\mathrm{O}_{2}\left(\mathrm{~b}^{1} \Sigma_{\mathrm{g}}{ }^{+}, v=0,1\right)$ relative yields in $\mathrm{O}\left({ }^{1} \mathrm{D}\right)$ $\mathrm{O}_{2}$ energy transfer. The Journal of Chemical Physics, Vol. 141, 024303, 2014. DOI: http://dx.doi.org/10.1063/1.4885721.

[63] R. P. Wayne, The photochemical formation of electronically excited oxygen molecules in the atmosphere, Quarterly Journal of Royal Meteorological Society, Vol. 93, No. 395, 69-78, 1967. https://doi.org/10.1002/qj.49709339506.

[64] U. Schurath, The energy pooling reaction $2 \mathrm{O}_{2}\left({ }^{1} \Delta \mathrm{g}\right) \rightarrow \mathrm{O}_{2}$ $\left({ }^{3} \Sigma_{\mathrm{g}}^{-}\right)+\mathrm{O}_{2}\left({ }^{1} \Sigma^{+} \mathrm{g}\right)$ formation, relaxation, and quenching of vibrationally excited $\mathrm{O}_{2}\left({ }^{1} \Sigma_{\mathrm{g}}^{+}\right)$, Journal of Photochemistry, Vol 4. No. 3, 215-226, 1975. https://doi.org/10.1016/00472670 (75)80007-4.

[65] J. M. C. Plane, Cosmic dust in the Earth's atmosphere, Chemical Society Reviews., Vol. 41, 6507-6518, 2012. DOI: 10.1039/C2CS35132C.

[66] V. Della Corte, F. J. M. Rietmeijer, A. Rotundi, M. Ferrari and P. Palumbo, Meteoric $\mathrm{CaO}$ and carbon smoke particles collected in the upper stratosphere from an unanticipated source, Tellus B: Chemical and Physical Meteorology, Vol. 65, No. 1, Article: 20174, 2013. DOI: 10.3402/tellusb.v65i 0.20174, https://doi.org/10.3402/tellusb.v65i0.20174.

[67] T. Vondrak, J. M. C. Plane, S. Broadley and D. Janches, A chemical model of meteoric ablation, Atmospheric Chemistry and Physics, Vol. 8, 7015-7031, 2008. www.atmos-chem-phys.net/8/7015/2008/.

[68] A. T. Stair, Jr, J. C. Ulwick, K. D. Baker and D. J. Baker, Rocketborne observations of atmospheric infrared emissions in the auroral region, pp. 335-346. In: B. M. Cormack (Ed), Atmospheres of Earth and Planets, 1975. 
[69] R. P. Wayne, Singlet oxygen molecule, pp. 311-371. In: J. N. Pitts, G. S. Hammond and W. A. Noyes (Eds), Advances in Photochemistry, New York, 1969.

[70] I. C. McDade and J. E. Llewellyn, The Altitude Dependence of the $\mathrm{O}_{2}\left(\mathrm{~A}^{3} \Sigma_{\mathrm{u}}^{+}\right)$Vibrational Distribution in the Terrestrial Nightglow, Planetary and Space Science, Vol. 30, No 11, 1135-1136, 1982.

[71] D. P. Murtaugh, I. C. McDade, R. G. H. Greer, J. Stegman, G. Witt and E. J. Llewellyn, Eton 4: An Experimental Investigation of the Altitude Dependence of the $\mathrm{O}_{2}\left(\mathrm{~A}^{3} \Sigma_{\mathrm{u}}{ }^{+}\right)$ vibrational Populations in the Nightglow, Planetary and Space Science, Vol. 34, No. 9, 811-817, 1986.

[72] A. Lofthus and P. Krupenie, The Spectrum of Molecular Nitrogen, Journal of Chemical Reference Data, Vol. 6, No. 1, 113-2307, 1977.

[73] J. A. Meyer, D. W. Setser and D. H. Stedman, Excitation of the auroral green line of atomic oxygen ${ }^{1} \mathrm{~S} \rightarrow{ }^{1} \mathrm{D}$ by $\mathrm{N}_{2}\left(\mathrm{~A}^{3} \Sigma^{+} \mathrm{u}\right)$, Astrophysical Journal, Vol. 157, 1023-1025, 1969

[74] https://www.timeanddate.com/astronomy/astronomical-twil ight.html.

[75] http://curious.astro.cornell.edu/about-us/161-our-solar-syste $\mathrm{m} /$ the-earth/day-night-cycle/189-how-do-sunrise-and-suns et-times-change-with-altitude-intermediate.

[76] https://en.wikipedia.org/wiki/Night.

[77] http://www.memagazine.org/backissues/membersonly/octo ber98/features/stratos/stratos.html.

[78] Mine Gases: Specific Gravity. https://miningquiz.com/dow nload/GasSpecificGravity.htm

[79] J. M. Flaud and R. Bacis, The ozone molecule: Infrared and microwave spectroscopy, Spectrochimica Acta Part A, Vol. 54, 3-16, 1998.

[80] K. Labitzke and B. Naujokat, The Lower Arctic Stratosphere in Winter since 1952, SPARC Newsletter, 15, 11-14, 2000. https://www.sparc-climate .org/fileadmin/customer/6_Publications/Newsletter_PDF/1 5_SPARCnewsletter_Jul2000_redFile.pdf.

[81] G. Günther, D. S. McKenna and R. Spang, Meteorological conditions of the stratosphere for the CRISTA 2 campaign, August 1997, Journal of Geophysical Research, Vol. 107, No. D23, CRI 12-1-CRI 12-10, 2002. DOI: 10.1029/2001JD000692.

[82] https://en.wikipedia.org/wiki/Charles\%27s_law.

[83] https://en.wikipedia.org/wiki/Moment_of_inertia.

[84] https://image.gsfc.nasa.gov/poetry/ask/a10840.html.

[85] E. Kyrölä, GOMOS/Envisat overview, Day 2 Lecture 5 Basics/Instruments, Dragon advanced training course in atmosphere remote sensing, ESA, NASCC, 2003. https://earth.esa.int/dragon/D2_L5_Kyrola.pdf.

[86] L. Moreira, K. Hocke, and N. Kämpfer, Comparison of ozone profiles and influences from the tertiary ozone maximum in the night-to-day ratio above Switzerland. Atmospheric Chemistry and Physics, Vol. 17, 10259 10268, 2017. https://doi.org/10.5194/acp-17-10259-2017. 